\title{
Earth Observations for Monitoring Marine Coastal Hazards and Their Drivers
}

\author{
A. Melet ${ }^{1}$ D $\cdot$ P. Teatini ${ }^{2} \cdot$ G. Le Cozannet ${ }^{3} \cdot$ C. Jamet $^{4} \cdot$ A. Conversi ${ }^{5} \cdot$ J. Benveniste $^{6}$. \\ R. Almar ${ }^{7}$
}

Received: 4 December 2019 / Accepted: 2 May 2020 / Published online: 5 June 2020

(c) The Author(s) 2020

\begin{abstract}
Coastal zones have large social, economic and environmental values. They are more densely populated than the hinterland and concentrate large economic assets, critical infrastructures and human activities such as tourism, fisheries, navigation. Furthermore, coastal oceans are home to a wealth of living marine resources and very productive ecosystems. Yet, coastal zones are exposed to various natural and anthropogenic hazards. To reduce the risks associated with marine hazards, sustained coastal zone monitoring programs, forecasting and early warning systems are increasingly needed. Earth observations (EO), and in particular satellite remote sensing, provide invaluable information: satellite-borne sensors allow an effective monitoring of the quasi-global ocean, with synoptic views of large areas, good spatial and temporal resolution, and sustained time-series covering several years to decades. However, satellite observations do not always meet the precision required by users, in particular in dynamic coastal zones, characterized by shorter-scale variability. A variety of sensors are used to directly monitor the coastal zone and their observations can also be integrated into numerical models to provide a full 4D monitoring of the ocean and forecasts. Here, we review how EO, and more particularly satellite observations, can monitor coastal hazards and their drivers. These include coastal flooding, shoreline changes, maritime security, marine pollution, water quality, and marine ecology shifts on the one hand, and several physical characteristics (bathymetry, topography, vertical land motion) of coastal zones, meteorological and oceanic (metocean) variables that can act as forcing factors for coastal hazards on the other hand.
\end{abstract}

Keywords Coastal zone $\cdot$ Earth observation $\cdot$ Monitoring $\cdot$ Hazards $\cdot$ Water quality $\cdot$ Flooding

\section{A. Melet}

amelet@mercator-ocean.fr

Extended author information available on the last page of the article 


\section{Introduction}

Coastal zones are the transition areas that connect the terrestrial and marine environment. The global coastlines exceed 1.6 million kilometers (Burke et al. 2001) and 84\% of the countries of the world have a coastline (either with the open oceans, inland seas or both).

Globally, coastal zones are more densely populated than the hinterland (Small and Nicholls 2003), exhibit higher rates of population growth and urbanisation, and are concentrating economic assets and critical infrastructures. The low-elevation coastal zone, defined as the contiguous and hydrologically connected zone of land along the coast with an elevation above sea level of less than $10 \mathrm{~m}$, covers only $2 \%$ of the world's land area but $\sim 10 \%$ of the world population lives there (McGranahan et al. 2007, Neumann et al. 2015). The growth of coastal population is projected to continue over the coming years, in response to population growth and coastward migration associated with the global trend of urbanisation. The world population is expected to reach 8.5 billion in 2030 and 9.7 billion in 2050 (projections of United Nations 2015) and most of the world's megacities are located in the coastal zone, many in large deltas (McGranahan et al. 2007). Coastal migration is also driven by the combinations of specific economic, geographic and historical conditions, concentration of densely settled agricultural areas in well-watered, fertile deltas and coastal plains (Hugo 2011; McGranahan et al. 2007).

Coastal zones represent a huge economic value. For instance, maritime transport is essential to the world economy as over $90 \%$ of the world trade is carried by sea, with large portions of maritime routes in the coastal ocean (International Maritime Organization). In 2010, the global ocean economy represented USD 1.5 trillion in added value, with a strong contribution from offshore oil and gas, maritime and coastal tourism, ports and maritime equipment, and ocean-based industries employment dominated by fisheries and maritime and coastal tourism (OECD 2016). In addition to these established activities, emerging ones are projected to grow in the coming decades, including marine aquaculture, ocean renewable energy, marine safety and surveillance (OECD 2016). By 2030, conservative estimates assess that ocean economy will grow to more than USD 3 trillion (in constant 2010 USD) much of which will rely on coastal tourism, offshore oil and gas and port activities. Marine aquaculture is estimated to grow at an annual rate of $5.7 \%$ between 2010 and 2030.

Coastal ecosystems are home to a wealth of terrestrial and marine flora and fauna. Marine coastal ecosystems are among the most productive on Earth and provide a range of social and economic benefits to humans. They yield $90 \%$ of global fisheries and almost $80 \%$ of known species of marine fish (Cicin-Sain et al. 2002). Reefs, mangroves and sand dunes also play a regulating role and protect the shoreline (Wells et al. 2006), for instance by largely attenuating the energy of wind-generated waves. Coral reefs are among the most biodiverse ecosystems on Earth, and together with river estuaries, have a high biomass productivity.

Therefore, coastal zones have a tremendous social, economic and biological value (Martínez et al. 2007). They are providing many services to human society, including food, energy and other resources, shoreline protection, ocean recreation, tourism and coastal livelihoods, water quality maintenance, waste treatment, biogeochemical cycling, and regulating services, support of the green and blue economy and importantly, the maintenance of the basic global life support systems.

However, coastal zones are exposed to different hazards of natural or anthropogenic origins (Fig. 1). Natural hazards can be driven by extreme states of the natural environment 


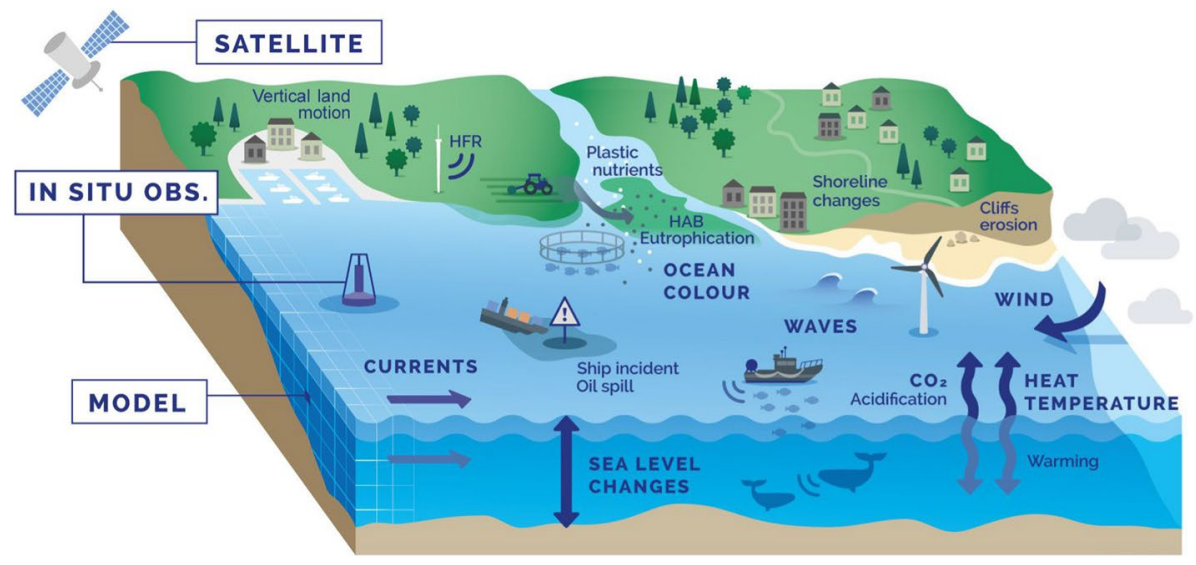

Fig. 1 Schematic representation (non-exhaustive) of the coastal zone, hazards (in normal font), and metocean variables (in bold font) that are relevant for coastal marine hazards and their monitoring [HFR: high-frequency radar; HAB: harmful algae bloom]

such as marine heat waves causing coral bleaching and fish mortality, large waves and extreme sea levels for coastal flooding, erosion and salinization of aquifers, low oxygen and acidification for degradation of ecosystems and habitats, etc. Several of them are exacerbated by climate change and induced ocean warming, acidification, and deoxygenation, sea level rise, increase in harmful algae blooms and invasive species (Gattuso et al. 2015; Bindoff et al. 2019).

The increasing development and utilisation of coastal zones (on land and ocean) over recent decades have led them to experience high pressures and have increased the vulnerability of coastal ecosystems (e.g., Crossland et al. 2005). Coastal hazards related to anthropogenic activities include maritime pollution, unsafe maritime conditions (e.g., for shipping and activities at sea), poor water quality, eutrophication, overfishing, degradation or loss of marine and coastal ecosystems and habitats, over-exploitation of subsurface fluids (groundwater, hydrocarbon) causing land subsidence. Forcing factors for marine coastal hazards are therefore widespread (Fig. 1).

Marine coastal hazards can lead to high risks for coastal zones due to the combination of high exposure (dense population, living marine resources, activities at sea, large economic assets and critical infrastructure) and vulnerability to these hazards in coastal areas (e.g., low adaptation capabilities of a given marine ecosystem to adapt to extreme or changing conditions, low capacity of a ship facing extreme wave conditions, etc.). Monitoring, understanding and predicting marine coastal hazards are therefore of increasing importance. A variety of sensors is used to monitor coastal zone characteristics, various metocean variables that are relevant for different coastal hazards, and some coastal hazards themselves. Metocean is the abbreviation of meteorology and oceanography and encompasses atmospheric and physical oceanographic variables such as characterizing wind, waves, sea level, bathymetry, currents, sea-ice (thickness, extent), seawater properties (salinity, temperature, stratification), water quality parameters.

Satellite-borne sensors allow an effective monitoring of the quasi-global ocean, with synoptic views of large areas in conjunction with good spatial and temporal resolution. Space observations can also allow to monitor multi-decadal changes as long time-series of 
space observations are now available for some variables (e.g., surface temperature). Satellite-borne sensors can be split into two different categories: passive and active ones (e.g., Le Traon et al. 2018). Passive techniques measure the natural radiation emitted from the sea or from reflected solar radiation in one or several spectral bands (wavelength bands) of the electromagnetic spectrum. Multispectral imagery generally has 3-25 bands of wavelength (13 for Sentinel-2), while hyperspectral imagery relies on hundreds of narrower spectral bands distributed across the electromagnetic spectrum. Passive sensors include microwave, infrared (thermal), and visible radiometers, imaging radiometers, spectro-radiometers and spectrometers. On the other hand, active sensors emit their own electromagnetic energy, potentially at wavelengths that are not energetic enough in sunlight and are then used for measuring the signal reflected, refracted or scattered by the Earth's surface or its atmosphere. As the majority of active sensors operate in the microwave portion of the electromagnetic spectrum, the emitted wave can penetrate the atmosphere and observe the ocean and the coastland under most conditions, including during the night, or cloudy conditions. Active sensors of particular importance for metocean and coastland monitoring include lidars, radar altimeters, synthetic or real aperture radars (SAR, RAR), and scatterometers.

The main aim of this article is to review how Earth Observations (EO), and more particularly satellite observations, can monitor several coastal zone characteristics that are relevant to hazard assessment (bathymetry, topography, vertical land motion, land cover and land use, in Sect. 2), metocean variables that can act as forcing factors for coastal hazards (Sect. 3) and coastal hazards themselves (Sect. 4). Among the various existing coastal hazards, attention is focused in Sect. 4 on coastland flooding and coastline dynamics, maritime security, marine pollution, water quality, and marine ecology shifts. Although of importance, coastal hazards related to ice (e.g., for navigation safety on sea-ice or ice-infested coastal waters, permafrost thaw, etc.) and plastic pollution (Viatte et al. 2020) are left out of this review, and so do the aspects related to the assessment of exposure and vulnerability, such as urbanisation and land management practices (Le Cozannet et al. 2020). Current gaps and perspectives or recommendations on using EO for a reliable evaluation and prediction of coastal hazards are discussed in the final section.

\section{Earth Observations to Characterize Coastal Zones}

Characterization of physical properties of the coastal zone is needed for coastal hazard assessments. In this section, we focus on EO monitoring of different essential physical properties of the coastal zone: land topography and ocean bathymetry, vertical land motion and land cover/land use.

\subsection{Bathymetry}

A great demand exists nowadays for up-to-date bathymetric (seafloor) and topographic (over land) maps of shallow water areas and adjacent emerged zones (e.g., beaches and sand barriers, lagoons, estuaries and mud coasts, cliffs). Indeed, estimates of the coastal zone topography and bathymetry with high spatial and temporal resolution and a good accuracy is a prerequisite to model or estimate different drivers of coastal hazards or hazards themselves (Cazenave et al. 2017). Inaccurate or outdated coastal Digital Elevation Models (DEMs) (including topography and bathymetry) lead to flooding modeling errors that can ultimately mislead coastal risk management (Neumann et al. 2015). 
Bathymetric measurements by ship- or air-borne echo-sounders and lidars are tedious and expensive. As a result, only a rather small fraction $(<15 \%)$ of the ocean depth has been determined at a horizontal resolution of at least $1 \mathrm{~km}$ (Mayer et al. 2018). In a large number of coastal areas of interest, bathymetric information is unavailable or is often decades old. Satellite observations are therefore an important complement to existing in situ observation systems, with the advantage of providing a more systematic monitoring (Benveniste et al. 2019). Satellite altimetry has allowed estimating the world's ocean bathymetry in deep water, but with an average achievable resolution of $8 \mathrm{~km}$. Satellite altimetry measures the sea surface height, which is notably affected by the gravitational effects of seafloor topographic features. The horizontal resolution of altimetry-derived bathymetry is much lower than direct measurements with echo-sounders, but it allowed mapping the seafloor over extended areas. Using satellite altimetry-derived bathymetry from Geosat and ERS-1 to guide the interpolation between direct depth soundings, Smith and Sandwell (1997) provided maps of the world's ocean bathymetry with a horizontal resolution of 1-12 km. These maps have been refined over time using new altimeter missions (e.g., Jason-1 and 2, SARAL/AltiKa geodetic missions, CryoSat-2) and will be further improved thanks to the future SWOT mission (Tozer et al. 2019).

In the coastal zone, satellite-derived bathymetry (SDB) can reach much finer horizontal resolutions thanks to two other methodologies (Pleskachevsky et al. 2011): methods based on the modeling of radiative transfer of light in water for the processing of optical images, and methods based on the influence of topography on hydrodynamic processes (e.g., current variations and wave characteristics); the latter ones can use optical or SAR images. Each method/sensor comes with its own strengths, limitations, and scope of applications (Gao 2009; Jawak et al. 2015). Specifically, methods based on the radiative transfer perform better in clear and calm waters, whereas techniques based on water depth inversion requires waves and can perform over turbid waters.

The pioneering technique using aerial multispectral photographs (Lyzenga 1978) was expanded to multi-spectral optical satellite images with first attempts made using Landsat data and then a wider application to other satellites such as Sentinel-2 (Caballero and Stumpf 2019; Evagorou et al. 2019; Sagawa et al. 2019). SDB is calculated based on the attenuation of radiance as a function of depth and wavelength in the water column, using analytical or empirical imaging methods. Analytical models are based on radiative transfer models and optical properties of the sea water, such as the attenuation coefficient and backscattering, the spectral signatures of suspended and dissolved matter, and bottom reflectance (Lee et al. 1998). Empirical methods are based on statistical relationships between image pixel values and ground truth depth measurements. Bathymetries can be estimated down to depths from a few meters (e.g., northern Baltic Sea) to 20-30 m (e.g., Mediterranean Sea) depending on the maximum penetration depth of sunlight, which varies with seasons, locations, turbidity, bottom reflectance, etc. The horizontal resolution of such bathymetries depends on the optical sensor, from coarse with for instance Landsat ( 30 $\mathrm{m}$ resolution), to medium with SPOT and Sentinel-2 (10 m resolution, Fig. 2), and to high with the use of commercial satellites such as IKONOS (1 m resolution) and QuickBird or WorldView (50-60 cm resolution) (Monteys et al. 2015). The accuracy of this method is equal to or is lower than with lidars or echo-sounders $(\sim 0.5 \mathrm{~m})$, but is an effective solution to map the nearshore bathymetry over large areas.

Other techniques for estimating bathymetry from optical images use wave characteristics (Abileah 2006; Danilo and Binet 2013; Poupardin et al. 2015), capitalizing on the methodologies developed by the coastal community (Holman et al. 2016) for video imagery and drones. This allows depths of up to $40-50 \mathrm{~m}$ to be resolved. Bathymetric 

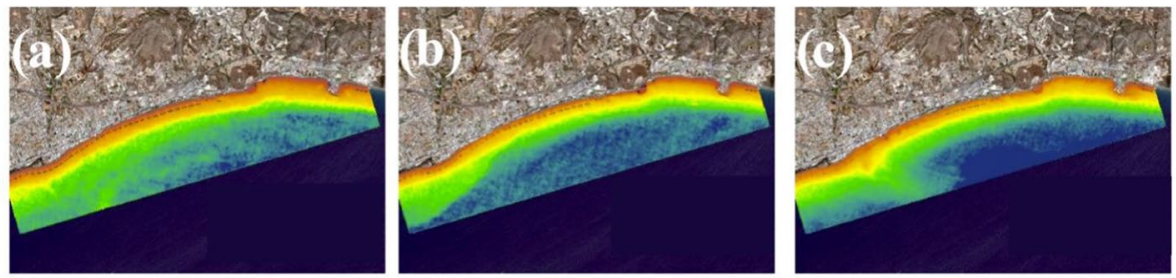

Estimated bathymetry $(\mathrm{m})$
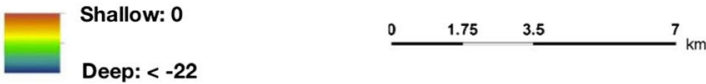

\section{(d) Profiles for SDB}

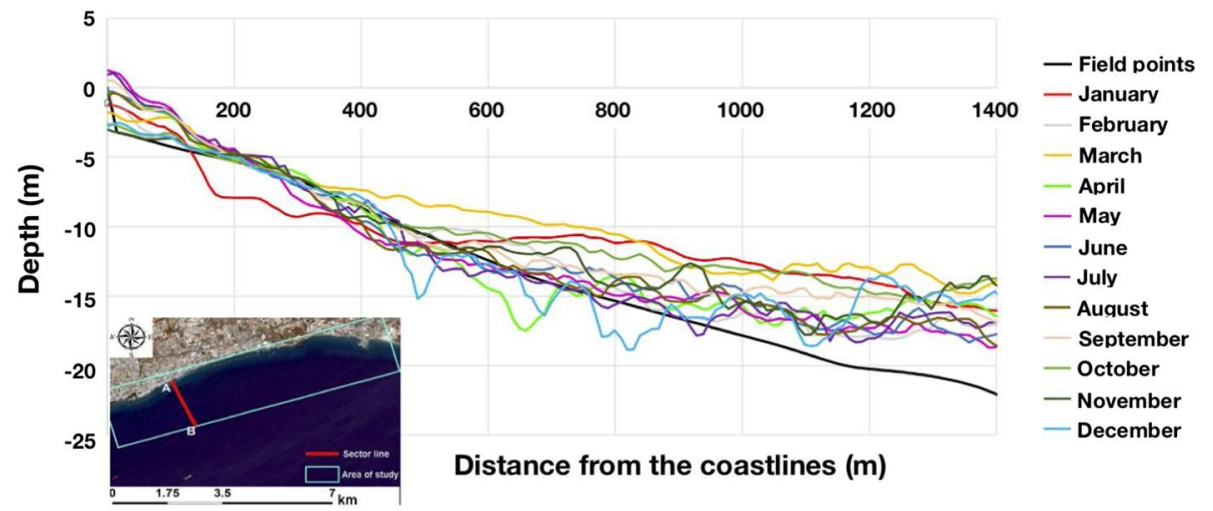

Fig. 2 Satellite-derived bathymetry (SDB) from Sentinel-2 multispectral optical data in a January 2018, b February 2018 and c March 2018 for depth shallower than $22 \mathrm{~m}$ over a coastal area of southern Cyprus. The monthly evolution of a bathymetric profile (shown in the lower inset) is shown in panel $\mathbf{d}$ from April 2017 to March 2018 with Sentinel-2 data. Field points correspond to LIDAR data acquired in 2014. Adapted from Evagorou et al. (2019)

inversion code developed from the wave dispersion relationship in intermediate to shallow water make use of the temporal information contained in the spatial images and were applied to different satellite observations: IKONOS (Abileah 2006), WorldView-2 (McCarthy 2010), SPOT5/6 (Poupardin et al. 2016), Sentinel-2 (Bergsma et al. 2019) and Pleiades (Danilo and Binet 2013; Almar et al. 2019). One of the great advantages of this approach is that it is autonomous and does not require additional wave information from observation or models besides those acquired by means of satellite remote sensing. Nearshore bathymetry can also be derived from SAR sensors, such as those on-board Sentinel-1 satellites. Similar to optical methods, shallow water bathymetry is derived from directional wave spectrum (e.g., Wiehle and Pleskachevsky 2018). At larger regional scale and for deeper waters, Alpers and Hennings (1984) proposed the first theoretical model to map bathymetry based on sea surface features induced by current variations over bottom topography. The range of validity of wave-based SDB does not depend on local calibration, water turbidity and bottom type, as color-based methods do, and this method can cover most shelves to depth up to 40-50 m (Bergsma and Almar 2020). However, color-based SDB seems to better resolve small-scale features in very shallow waters, so that a combination of methods is beneficial. 
It is noteworthy that a recently increasing number of works make use of deep learning (Sagawa et al. 2019) that brings great expectations to solve satellite-based bathymetry issues of complex physics and environments, method fusion and computational costs (Danilo and Melgani 2019).

Coastal morphology changes over a wide range of timescales (from storm events, seasonal and interannual variability to longer-term adaptation to changing environmental conditions), in particular in response to changing incoming wave regimes (e.g., Karunarathna et al. 2016; Bergsma et al. 2019, Fig. 2d) and human interventions. Despite its high potential, SDB has only been applied to limited space domains, and efforts remain to be done to map nearshore bathymetry and its time-evolution at global scale (e.g., Mayer et al. 2018; Wölfl et al. 2019; Benveniste et al. 2019).

\subsection{Coastal Land Topography}

Several methods exist for mapping the coastal topography (see recent review by Salameh et al. 2019) using various passive (SPOT, Landsat-8/OLI, Sentinel-2/MSI, WorldView, Quickbird, IKONOS, Pléiades, etc.) and active (ERS-1\&2, ENVISAT, TerraSAR-X, Sentinel-1, etc.) sensors. Satellite remote sensing techniques now offer a good alternative for digital elevation model (DEM) construction over large spatial areas with sufficient horizontal resolution $(<100 \mathrm{~m})$. Global DEMs such as the $90 \mathrm{~m}$ resolution SRTM (Farr et al. 2007) (widely used for broad scale flood modeling, e.g., Ettritch et al. 2018; Neumann et al. 2015; Kulp and Strauss 2018), $30 \mathrm{~m}$ resolution ALOS AW3D30 (JAXA, Tadono et al. 2016, recently released and used incipiently by Zhang et al. 2009) and $8 \mathrm{~m}$ resolution WorldDEM (Airbus, on-demand) are available. However, they are often years old and do not reflect the rapid evolution of dynamic coastal areas.

By analyzing stereoscopic pairs of satellite optical images (Tateishi and Akutsu 1992), it is possible to study large coastal areas with vertical errors of less than $0.5 \mathrm{~m}$. Examples using Pleiades are given in Collin et al. (2018) and Almeida et al. (2019) (Fig. 3). Intertidal areas between spring tides also benefit from the wide range of satellite data available. The waterline method for intertidal topography mapping introduced by Mason et al. (1995) is one of the most widely adopted techniques. The method consists in determining the horizontal position of the shoreline using SAR (Heygster et al. 2010; Li et al. 2014) or optical images (Bergmann et al. 2018; Khan et al. 2019), and then superimposing the heights above mean sea level obtained from the knowledge of tide and surge on this boundary. For multiple images obtained over a range of different waterline levels, a set of elevated shorelines can be constructed and from there, a raster DEM can be interpolated.

Over the last decade, other methods have also proven reliable for monitoring the topography of coastal flat areas. Specifically, highly accurate DEMs have been obtained by processing SAR images acquired by Tandem missions. ESA conducted between 27 September 2007 and 12 February 2008 a dedicated ERS-2-ENVISAT Tandem mission. A unique opportunity offered by these two SAR instruments operated in the same orbital configuration was ERS-ENVISAT cross-interferometry. ENVISAT was operated in the same orbits as ERS-2, preceding ERS-2 by approximately $28 \mathrm{~min}$. The almost simultaneous acquisition of SAR images by the two satellites and a large perpendicular baseline of approximately $2 \mathrm{~km}$ between the two satellites for mid to high northern latitudes allowed the generation of precise DEMs in relatively flat areas (Wegmüller et al. 2009). Similarly, cross satellite SAR interferometry based on two TerraSAR-X radar satellites flying in close formation has been made available by TanDEM-X (TerraSAR add-on for Digital Elevation Measurement-TDX) mission. The 


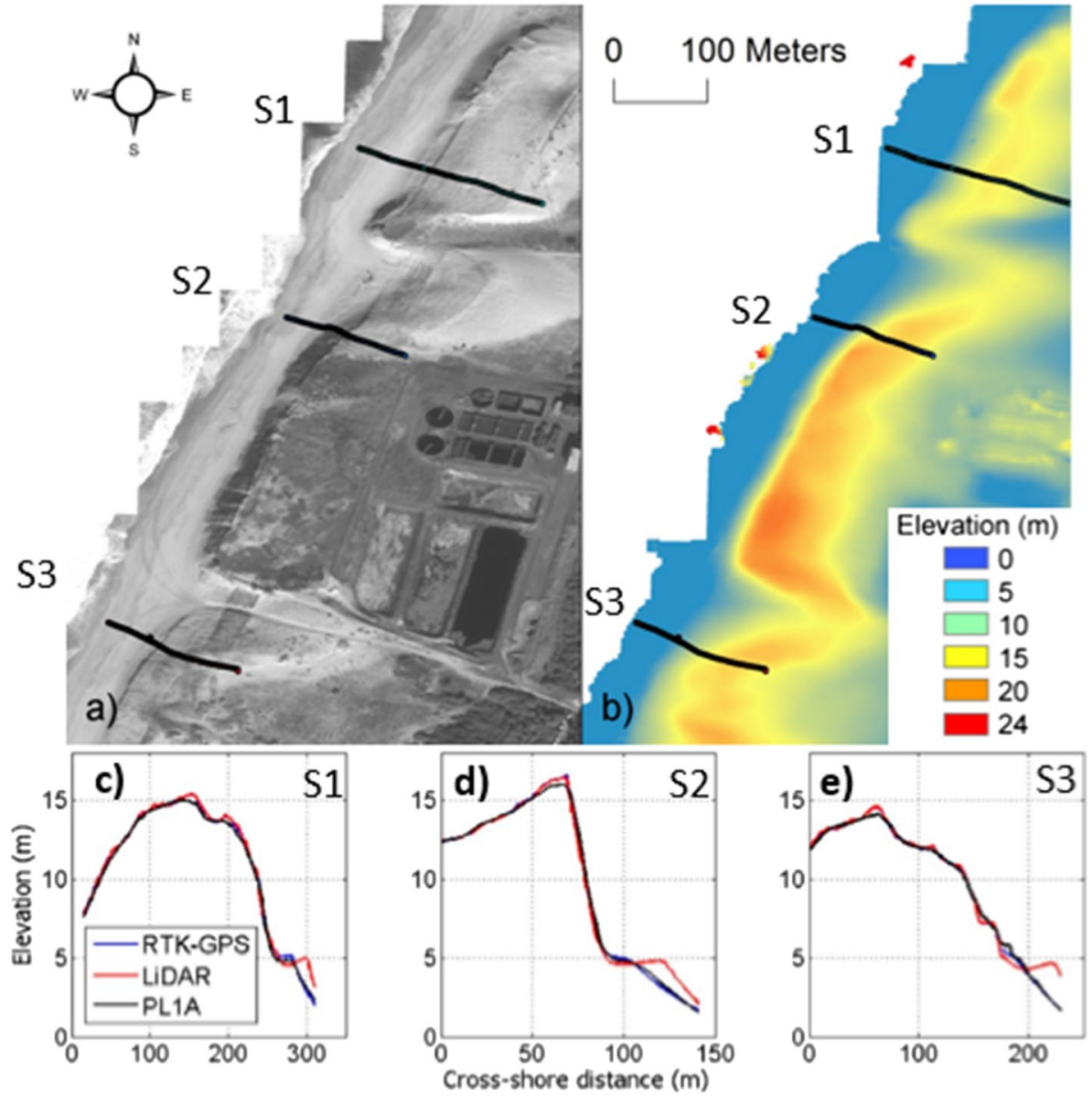

Fig. 3 a Orthophoto and b digital Surface Model from Pleiades stereo pair showing the locations of the transects S1, S2, S3 for comparison of beach profiles between the RTK-GPS, Pleiades (PL1A) and LiDAR data shown in panel $\mathbf{c}$ for $\mathrm{S} 1, \mathbf{d}$ for S2 and e for S3 (from Almeida et al. 2019)

TDX datasets acquired using a short-term or no temporal baseline (10 s), a large spatial baseline (3 to $4 \mathrm{~km}$ ), and a high-resolution imaging mode ( 5 to $7 \mathrm{~m}$ ) provided a great opportunity to generate DEMs with significantly improved vertical accuracy (height error in the range of 0.10-0.15 m) over intertidal environments (Lee and Ryu 2017; Choi and Kim 2018). Overall, vertical errors of $0.2 \mathrm{~m}$ or less correspond to current requirements for local high-resolution flood modeling (Le Roy et al. 2015; Ablain et al. 2016). While such accuracies in urbanized zones can only be achieved with lidar today, other products are useful for broad scale modeling, as well as in areas characterized by flooding by overflow and lack of data.

\subsection{Vertical Land Motion}

The capability of monitoring the vertical movements of the Earth surface, and specifically land subsidence in coastal areas, has increased significantly over the last two decades 
with the availability of satellite SAR acquisitions and the simultaneous development of interferometric processing chains (e.g., Teatini et al. 2005; Chaussard et al. 2013; Higgins et al. 2014; Tosi et al. 2016; Da Lio et al. 2018). Several SAR-borne satellites have been in operation since 1991 (ERS-1/2; ENVISAT; JERS-1; RadarSAT-1/2, ALOS, TerraSAR-X, Cosmo-SkyMed, and Sentinel-1A\&B from the mid-2014), thus a large satellite SAR data archive exists over many areas. Differential SAR Interferometry-DInSAR (Gabriel et al. 1989), Permanent Scatterer InSAR_-PSInSAR (Ferretti et al. 2001), Small Baseline Subset-SBAS (Berardino et al. 2002), Interferometric Point Target Analysis-IPTA (Wegmüller et al. 2004), and 'Squeezed"' SAR—SqueeSAR (Ferretti et al. 2011) are only the most well-known and widely used SAR processing chains among a continuously increasing variety of algorithms.

The quantification of land subsidence in coastlands has always been challenging for traditional ground-based methods (e.g., levelling, GNSS) because of the peculiarity of lowlying coastal zones. On the one hand, in natural conditions coastlands are characterized by difficult access due to the presence of marshlands, lagoons, and watercourses. On the other hand, the use of in situ techniques in large urban settlements and megacities (which are continuously growing in coastal zones worldwide) usually provides an over-simplified representation of the actual pattern of the land displacements due to the limited number of monitoring locations (benchmarks or GNSS antennas). By exploiting the phase difference of the radar signals between or among a number (at least two) of satellite acquisitions over the same area, SAR-based techniques can provide movement information on millions of points scattered over a large region $\left(10^{4}-10^{5} \mathrm{~km}^{2} / \mathrm{scene}\right.$ ), with a high spatial detail (image horizontal resolution is on the order of $25 \times 25 \mathrm{~m}^{2}$ or less depending on the acquisition mode), a sub-centimeter measurement accuracy, and a temporal sampling from a few days to one month (Ferretti et al. 2001). Therefore, levelling and GNSS have been less and less used over recent years to measure land subsidence. However, it must be emphasized that they remain of paramount importance in calibrating the SAR outcome (e.g., Tosi et al. 2016) and converting SAR differential displacements to absolute measurements (Wöppelmann et al. 2013).

Specific approaches have been developed over the recent years to increase the effectiveness of SAR-based applications to monitor land motion in coastal areas. Specifically, the low coherence in vegetated areas and the lack of radar reflectors in the most natural portions of lagoons and deltas has been overcome by establishing artificial reflectors (Strozzi et al. 2013). Moreover, various strategies have been proposed to obtain the best advantage from SAR sensors with different frequency bands by means of the integration of their outcomes (e.g., Cianflone et al. 2015; Tosi et al. 2016) (Fig. 4).

\subsection{Land Cover and Land Use}

Information on land cover/land use (LCLU) and their changes are of relevance for several coastal hazards. For instance, during coastal flooding (Sect. 4.1), water level attenuation due to hydrodynamic processes related to the land surface roughness, which depend on LCLU, can substantially reduce the areas, population and asset exposure to flooding (Vafeidis et al. 2019). LCLU products have been derived from satellite data for decades (Ban et al. 2015). For instance, the latest CORINE dataset is based on Sentinel-2 and Landsat-8 EO. Yet, mapping LCLU in the coastal zone with enough resolution (space and time) and relevant classification to better address coastal hazards and exposure is still needed. Characterizing the coastal geology (Fig. 5a, b) is also needed to assess the vulnerability 

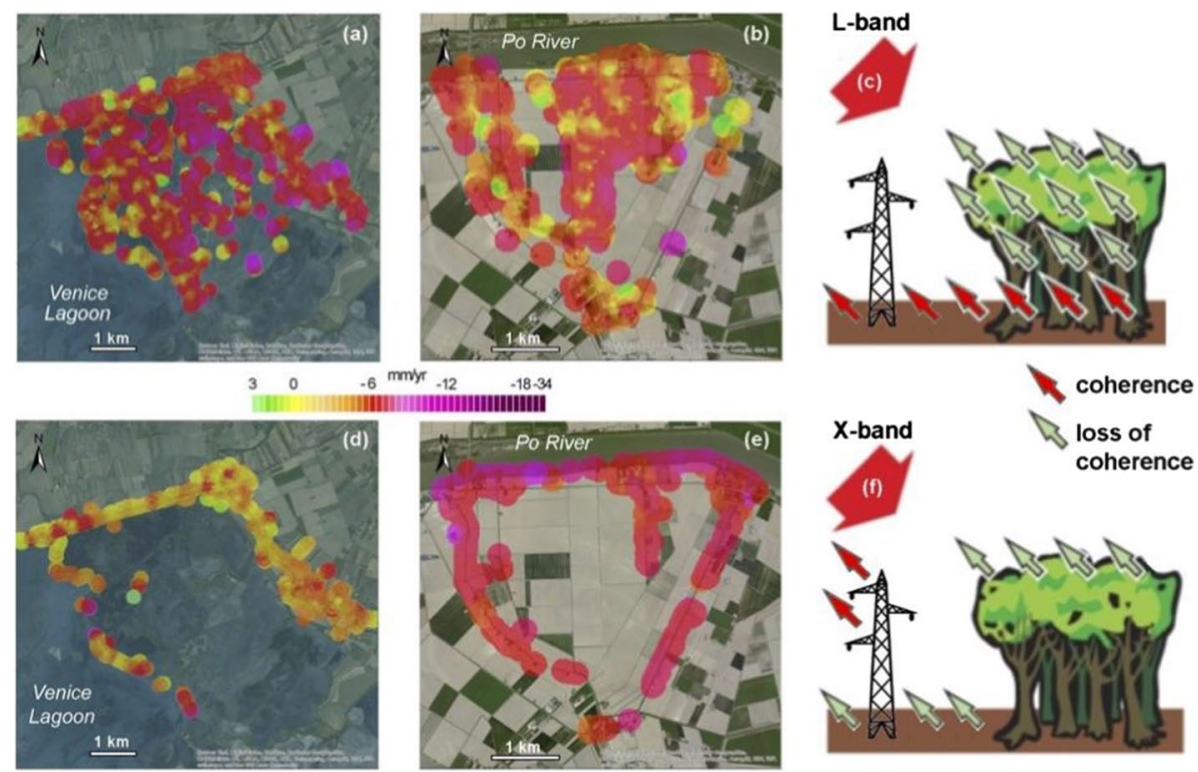

Fig. 4 Comparison of SAR outcomes on $\mathbf{a}, \mathbf{d}$ the northernmost tip of Venice Lagoon and $\mathbf{b}$, $\mathbf{e}$ a portion on the Po River delta, Italy. Positive values (in green) mean uplift while negative values (yellow to purple) mean land subsidence. The movements in $\mathbf{a}, \mathbf{b}$ were obtained by SBAS on 16 L-band images acquired by ALOS-PALSAR between 2007 and 2010; those in d, e by PSI on 30 X-band Cosmo-SkyMed images from 2008 to 2011. The capability of L-band and X-band images to detect different radar targets are represented by the sketches in c, f: L-band acquisitions processed by SBAS provide information on fields and wetlands, $\mathrm{X}$-band PSI on anthropogenic structures and infrastructures mainly located along roads and embankments. Notice how, on average, these latter subsided more in the Po Delta and less in the Venice Lagoon than the farmland and wetland surface, respectively. Subpanels a, b, d, e modified after Tosi et al. (2016)

of the shoreline. For instance, granite cliffs are less prone to erosion than sandy beaches. The detection of sandy beaches with EO is developing (e.g., Luijendijk et al. 2018). LCLU information is also relevant for eutrophication and water quality (Sect. 3.4) due to nutrient loading from, e.g., agricultural practices (Fig. 1).

\section{Monitoring Relevant Variables for Marine Coastal Hazards}

In addition to the above coastal zones characteristics, different metocean fields need to be monitored for a better assessment and monitoring of coastal hazards. The most important variables to monitor include sea surface temperature, sea level, ocean surface currents, near surface wind, ocean color, but also sea ice parameters, water turbidity, $\mathrm{pH}$, nutrients and oxygen concentrations, not discussed in this article. These variables can directly drive coastal marine hazards, or their monitoring contributes to understand or estimate them. Table 1 exemplifies such relationships for a selection of marine coastal hazards discussed in Sect. 4. Various variables of the marine environment can be monitored with a global or quasi-global coverage and at synoptic scales thanks to different satellite-based instruments, such as optical imagers, spectroradiometers, infrared or microwave radiometers, altimeters, synthetic or real aperture radars, etc. (see Benveniste et al. in review). We briefly describe 
below EO of the most relevant environmental data for marine coastal hazards, which are also essential climate variables (ECV as defined by the Global Climate Observing System), with a focus over the coastal ocean.

\subsection{Sea Level}

Tide gauges provide the fundamental observations of local sea level changes at the coast (relative to the ground level, as they are grounded on land), with the first records dating back to the eighteenth century. Furthermore, tide gauges are the main source of high-frequency $(<1 \mathrm{~h})$ sea level observations, which are essential for observing extreme water levels at the coast (e.g., Woodworth et al. 2017). However, tide gauge observations come with several limitations. The tide gauge coverage is rather sparse and inhomogeneous along the world's coastlines; some processes such as wave setup are not fully captured due to the location of tide gauges in wave-sheltered areas. GNSS stations tied to tide-gauges are required to provide vertical land motion over extended periods of time, but are often lacking (see Marcos et al. 2019).

Satellite altimetry, with its quasi-global coverage and rather high revisit time, complements tide gauge data. Sea surface height in the open ocean has been accurately monitored by satellite altimetry since late 1992 thanks to a suite of different altimetry missions (e.g., Cazenave et al. 2018). These space observations have largely improved our understanding of sea level variability, and have allowed a precise monitoring of sea level rise, with a global-mean rate of $3.35 \pm 0.4 \mathrm{~mm} / \mathrm{yr}$ and an acceleration of $0.12 \pm 0.7 \mathrm{~mm} / \mathrm{yr}^{2}$ over 1993-2017 (WCRP Global sea level budget group 2018, Ablain et al. 2019). But despite the recognized invaluable contribution of satellite altimetry to better monitor sea level and ocean dynamics over most of the world's ocean, conventional satellite altimetry methods remain unable to monitor the sea level changes in the coastal zone. The poorer performances of satellite altimetry in the last kilometers $(\sim 20 \mathrm{~km})$ off the coasts are due to land contamination in the radar footprint that modifies in a complex way the radar waveform, and to less accurate geophysical corrections (e.g., Birol et al. 2016; Cipollini et al. 2017; Benveniste et al. 2019). Yet, monitoring sea level close to the coast is much needed as sea level variability at the coast can differ from that of the open ocean (e.g., Vinogradov and Ponte 2011; Bingham and Hughes 2012; Calafat et al. 2012; Hughes et al. 2019), from weather event to multi-decadal timescales (Melet et al. 2018; Ponte et al. 2019), due to different dynamics and to the additional contribution of processes to these captured by satellite altimetry in the open ocean. Among them are tides, wind setup, surface atmospheric pressure effects, coastally trapped waves, wind-wave setup and swash, river runoffs or even more local processes such as seiches or meteotsunamis (Woodworth et al. 2019). Over the last years, coastal altimetry has substantially progressed thanks to specific waveform retracking (e.g., Passaro et al. 2014, 2018), improved geophysical corrections and data editing (Birol et al. 2016), or altimetry missions with smaller footprint (SARAL/AltiKa Ka-Band altimeter) or higher along-track resolution (CryoSat-2 and Sentinel-3A\&B delayDoppler Altimeters). Efforts are undertaken to combine specific waveform retracking, improved data editing and corrections to study sea level changes as close to the coast as possible (e.g., Marti et al. 2019).

In addition, altimetry faces sampling issues regarding high-frequency variations (e.g., associated to surges, tides, seiches, tsunamis) since revisit times are, at best, 10 days. Similarly, extreme events, which obviously matter in terms of coastal hazards, are highly localized in space and time while altimetry tracks are separated by tens of kilometers. As such, 
altimetry is not yet an alternative to tide gauges when it comes to monitoring high-frequency variations and sea level at the coast.

In practice, all mean and extreme sea level observations are limited in time and spatial resolutions: this includes satellite altimetry, tide gauges and other sea level monitoring approaches (e.g., SAR, Raucoules et al. 2018, GNSS reflectometry, Roussel et al. 2015). As no single approach can currently respond to the demand for information on mean and extreme sea levels, the synergic use of different observations and modeling approaches can be suggested as one way forward to progress in this area.

\subsection{Sea Surface Temperature (SST)}

Satellite-derived observations of SST are actually representative of different depths that depend on the passive sensor frequency. Infrared (IR) sensors measure the surface skin temperature $(\mathrm{O}(10) \mu \mathrm{m})$, which can be affected by cool skin layer effects, especially at night, and warm layer effects in the daytime, in addition to potential diurnal warming. Microwave (MW) sensors measure the subskin temperature $(\mathrm{O}(1) \mathrm{mm})$, below the thermal skin layer, and capture less the diurnal SST variability. MW sensors have a footprint of $\sim 50-75 \mathrm{~km}$, which limits the retrieval of SST data $\sim 100 \mathrm{~km}$ inshore due to land contamination, but they present the advantage of being mostly insensitive to clouds. Infrared (IR) sensors on the other hand provide SST at a resolution of $1-4 \mathrm{~km}$, but are strongly influenced by cloud emission and scattering. MW and IR SST retrievals are merged to provide global maps of SST. Retrieval of SST in the coastal zone also tends to be less accurate than in the open ocean due to a larger variability in atmospheric temperature, water vapor and aerosol concentrations, or due to potential alteration of the ocean surface emissivity related to contaminants, and to the lack of in situ data that are needed to validate SST retrievals. Diurnal warming of the sea surface has been relatively less studied in the coastal ocean than in the deep ocean. In the coastal zone, diurnal warming is influenced by several factors, such as sea breezes, bathymetric and tidal effects, in addition to the usual factors of solar insolation and surface winds. Diurnal warming can be of relevance for hazards related to ecosystems. For instance, coral bleaching events could be related to maximum daily temperatures. Improving EO derived SST quality in the coastal zone is a priority for SST developments in the next decade (see O'Carroll et al. 2019 for a review on SST EO).

\subsection{Surface Wind-Waves}

Significant wave height, the average height of the highest one-third of the waves, can be inferred from satellite altimetry (e.g., Ribal and Young 2019; Ardhuin et al. 2019). Such observations suffer from similar limitations than those described for satellite altimetry sea level in the coastal zone (Sect. 3.1), and can similarly be improved with retracking, data filtering, and reduction of the radar footprint (Passaro et al. 2015; Quilfen et al. 2018; Dinardo et al. 2018). More complete information on the wave field can be obtained from directional wave spectrum derived from C-band SAR sensors (e.g., ERS-1, ERS-2, Envisat, Sentinel-1), enabling the monitoring of the wave directions and periods (e.g., Hasselmann et al. 2012), which are essential parameters in addition to significant wave height for wave-contributions to sea level at the coast. Yet, SAR wave-mode based wave period estimates are mostly reliable for long swells (with a wavelength longer than $200 \mathrm{~m}$, Ardhuin et al. 2019) due to blurring effects induced by wave orbital velocities. Another limitation in coastal zones comes from acquisition modes: for instance, although Sentinel-1 

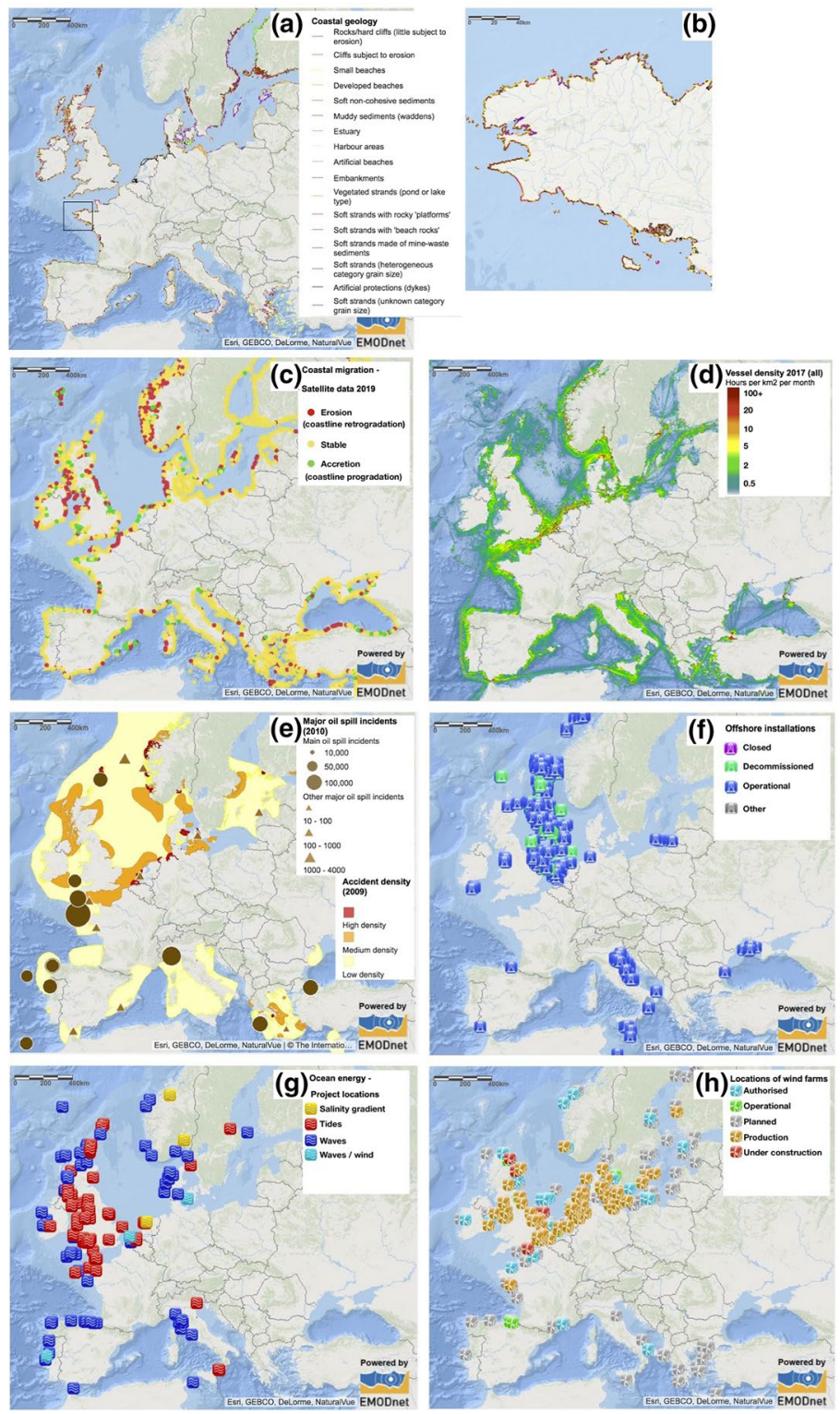

Fig. 5 a Coastal geology of the EU shoreline. Credit: EUROSION database, EMODnet. b Zoom over French Brittany. c Shoreline migration over 2007-2017 estimated from Sentinel-2, Landsat 5, 7 and 8 satellite data. Credit: EMODnet. d Shipping density in $1 \mathrm{~km} \times 1 \mathrm{~km}$ cells for 2017 over all EU waters, based on AIS data and expressed as hours per square kilometer per month. Credit: Cogea, EMODnet. e Shading: Shipping accident density in the seas around the European Union for year 2009. Credit: EMSA, EMODnet. Brown circles and triangles: major oil spill accidents for years 2007-2008, units: tonnes. Credit: EMSA, EMODnet. f Offshore structures and facilities in a marine environment, usually for the production and transmission of electricity, oil, gas and other resources. Credit: OSPAR, EMODnet. g Marine energy project locations depending on the marine source of energy. Credit: EMODnet. h Location and status of offshore wind farms over EU water. Credit: EMODnet 
Table 1 Relevance of metocean variables for a selection of different coastal hazards

\begin{tabular}{lllllll}
\hline EO observations & \multicolumn{2}{l}{ Coastal hazards } & & & \\
\cline { 2 - 6 } & Flooding & $\begin{array}{l}\text { Shoreline } \\
\text { changes }\end{array}$ & $\begin{array}{l}\text { Maritime } \\
\text { security } \\
\text { hazards }\end{array}$ & $\begin{array}{l}\text { Maritime } \\
\text { pollution }\end{array}$ & $\begin{array}{l}\text { Degraded } \\
\text { water quality }\end{array}$ & Ecosystem shifts \\
\hline Sea level & $\mathrm{x}$ & $\mathrm{x}$ & $\mathrm{x}$ & & $\mathrm{x}$ & $\mathrm{x}$ \\
SST & & $\mathrm{x}$ & $\mathrm{x}$ & $\mathrm{x}$ & $\mathrm{x}$ & $\mathrm{x}$ \\
Wind-wave & $\mathrm{x}$ & $\mathrm{x}$ & $\mathrm{x}$ & $\mathrm{x}$ & & \\
Surface currents & & $\mathrm{x}$ & $\mathrm{x}$ & $\mathrm{x}$ & $\mathrm{x}$ \\
Surface winds & $\mathrm{x}$ & $\mathrm{x}$ & & $\mathrm{x}$ & $\mathrm{x}$ & \\
Ocean color & & & & & & $\mathrm{x}$ \\
\hline
\end{tabular}

acquires in the default wave-mode over most of the world open ocean, an interferometric wide-swath mode (IW) is operated over coastal zones. Algorithms are being developed to retrieve directional wave spectra from IW Sentinel-1 acquisitions.

The wave scatterometer SWIM on-board CFOSAT (launched in October 2018) recovers wave spectra for shorter waves, down to wavelengths of $70 \mathrm{~m}$. Yet, C-band SAR or $\mathrm{Ku}-$ band RAR (such as SWIM) are still limited in enclosed basins and off eastern coasts, due to blurring associated with wave-induced orbital motions, short wave periods and heights, and wave direction close to the azimuthal direction (Alpers and Rufenach 1979; Dodet et al. 2019). Optical imagery (e.g., Sentinel-2, Landsat) can also provide the full directional wave spectrum in coastal areas (Kudryavtsev et al. 2017).

\subsection{Near Surface Wind}

The sea surface roughness is related to centimetric scale waves (capillary waves) formed by the wind stress on the ocean surface. As the sea surface reflectivity and emissivity depends on sea surface roughness, remote sensing of near surface winds exploits the relationships between wind speed and direction and sea surface roughness. Near surface wind speed and direction have both been retrieved and monitored over the global ocean by satellite radar scatterometers (e.g., Seawinds on-board QuikSCAT; SCAT onboard CFOSAT, HY2A, HY2B) (de Kloe et al. 2017). However, the spatial resolution of current scatterometers is of order $12-25 \mathrm{~km}$, which is a limitation for coastal zone monitoring. Higher resolution wind retrieval, as close as 1-2 km off the coast, are possible thanks to SAR imagers. Yet, SAR only enables wind speed retrieval through a priori knowledge of wind direction and the inversion of backscattering using semi-empirical models developed for scatterometers. In the coastal zone, SAR backscattering can be hampered by waves and currents, bathymetry and topography (including capes and islands) and SST fronts. These phenomena can affect sea surface roughness (Zechetto et al. 2016) and can also generate small-scale features $(<25 \mathrm{~km})$ in the near surface wind field (Chelton et al. 2004). Differential diurnal warming between land and ocean surfaces can also generate small-scale variability in the coastal zone wind field. Microwave radiometers and satellite altimetry can also provide long-term observations of wind speed, but do not provide wind direction and have limited performance in the coastal zone (Sects. 3.1, 3.3). 


\subsection{Ocean Surface Currents}

Direct near-real time high-resolution 2D observations of surface currents can be provided by coastal high-frequency radars (HFR) (e.g., Ullman et al. 2006; Roarty et al. 2019). HFR have a measurement range of approximately 20-200 km offshore with a spatial resolution ranging from $300 \mathrm{~m}$ to $12 \mathrm{~km}$, depending on their operating frequency. However, they cover comprehensive portions of the coastlines only for some countries, such as the USA. Geostrophic surface currents can be derived from satellite altimetry observations of sea level with a quasi-global coverage. Yet, altimeter-derived geostrophic currents might only be partly resolved in shelf seas, where the dominant spatial scale of ocean baroclinic mesoscale eddies, characterized by the first baroclinic Rossby deformation radius, is smaller than the effective resolution of altimeter products. Altimeter-derived geostrophic currents can then be complemented, and their resolution potentially increased, through synergetic use of information from surface winds to account for Ekman currents (e.g., Rio et al. 2014; Sudre et al. 2013; Dohan and Maximenko 2010; Bonjean and Lagerloef 2002) and from SST, by inverting the heat conservation equation, to partly account for other ageostrophic currents (e.g., Rio and Santoleri 2018). However, such techniques remain hampered by the limitations of satellite altimetry in the coastal zone (Sect. 3.1) and do not give access to the total surface currents. In particular, Stokes drift and tidal currents can account for a large fraction of the total currents in some areas (Fig. 6).

\subsection{Ocean Color}

Ocean color radiometry (OCR) results from the interaction of sunlight with the marine particles, which encompass pure water, phytoplankton through the common pigment (chlorophyll-a), the suspended particulate matter (SPM) and Colored Dissolved Organic Matter (CDOM), virus, bacteria (Antoine 1998; IOCCG 2000; Sosik 2008). These marine particles can absorb and scatter more or less the sunlight in specific directions and at preferential wavelengths.

Remote sensing of OCR has revolutionized our vision of the distribution of the marine biomass. The first ocean color sensor, the Coastal Zone Coastal Scanner, was launched in 1978 and was a proof-of-concept. Since 1997, a new generation of remote sensors has been developed and put on satellite platforms leading to 20 +-year records of satellite observations.

The primary parameter that can be estimated via remote sensing of ocean color is the so-called Remote Sensing Reflectance, $\mathrm{R}_{\mathrm{rs}}$ (IOCCG 2000), which represents the quantity of light back-scattered by the ocean. The shape and magnitude of this spectra depend on the concentration and types of marine particles. From this parameter, a variety of bio-optical and biogeochemical parameters can be derived (IOCCG 2000, 2018) from empirical or semi-analytical algorithms (Matthews 2011; Odermatt et al. 2012; Blondeau-Patissier et al. 2014; IOCCG 2018; Werdell et al. 2018). In turn, these parameters provide very useful information for monitoring the water quality, especially over coastal zones: chlorophyll-a concentration and primary production, suspended particulate matter, particulate and dissolved organic carbon, particulate inorganic carbon, phytoplankton groups, transparency/ turbidity (IOCCG 2008, 2018).

Historically, remote sensing of ocean color used sensor with high radiometric and spectral resolutions, medium-spatial resolution (300-1000 m) and high revisit times (typically, 3 days). But high-spatial-resolution sensors $(10-100 \mathrm{~m})$ with relevant radiometric and 


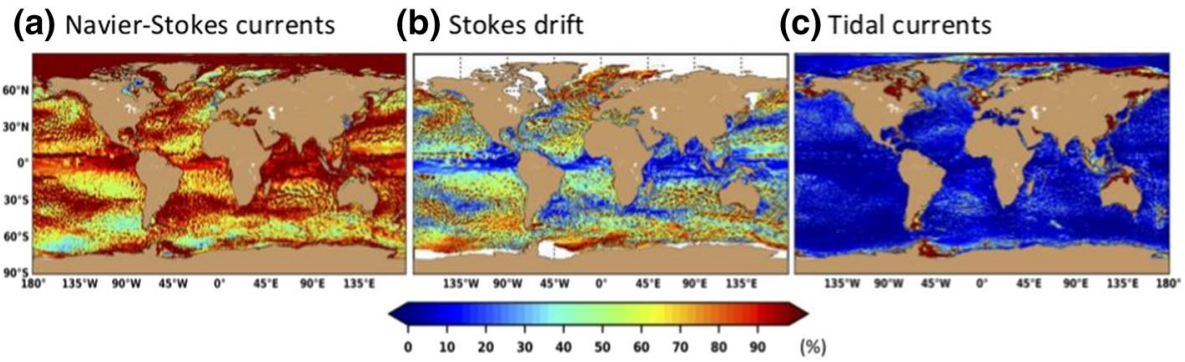

Fig. 6 Monthly averaged contribution in percentage to the magnitude of surface currents from a the ocean general circulation (stemming from Navier-Stokes equations), b wave-induced Stokes drift and $\mathbf{c}$ tidal currents for March 2018 in CMEMS product SMOC (product global-analysis-forecast-phy_001_024-hourlymerged-uv). Courtesy Stéphane Law Chune (Mercator Ocean International)

spectral resolution are now allowing water quality and pollution to be tracked over coastal areas (OLI/Landsat 8 and MSI/Sentinel-2 sensors). Efforts were undertaken these last years to adapt these sensors to aquatic science applications: water pixel extraction (Ngoc et al. 2019), atmospheric correction (Vanhellemont and Ruddick 2014, 2015, 2018), validation (Ody et al. 2016; Pahlevan et al. 2017a, b, 2018, 2019; Warren et al. 2019). Geostationary satellites (SEVERI, GOCI-I, Himawari-8) can also provide very useful information over coastal areas, even if some of them were not designed for ocean applications, as several images are taken per day with a current resolution ranging from $3 \mathrm{~km}$ (SEVIRI) to 500 $\mathrm{m}$ (GOCI-I) (Himawari-8: spatial resolution of $500 \mathrm{~m}$ to $1 \mathrm{~km}$ in the visible bands, $2 \mathrm{~km}$ in infrared bands) (Neukermans et al. 2009, 2012; Salama and Shen 2010; Ruddick et al. 2013; Choi et al. 2014; Doxaran et al. 2014; Vanhellemont et al. 2014; Huang et al. 2015; Kwiatkowska et al. 2016; Dorji and Fearns 2018). Issues still remain to have a complete system able to monitor coastal areas at high spatial and temporal resolutions (Mouw et al. 2015).

\subsection{Integration of EO in Models and Forecasting}

While satellite observations are an essential source of information to monitor metocean variables that are relevant to coastal hazards, they are often limited to the ocean surface, and do not provide a full spatial and temporal synoptic coverage of the ocean surface. Integrating satellite observations of the ocean surface and sparse in situ coastal observations into operational numerical global, regional or coastal models enables a synoptic 4D monitoring of the many ocean variables, including those non-observed variables, and improves the models' accuracy and prediction skills (e.g., Le Traon et al. 2015; Tonani et al. 2015). The more commonly assimilated satellite observations in ocean models are SST, sea level, Chlorophyll-a concentration, significant wave height (with progress regarding the assimilation of directional wave spectra), and sea-ice parameters. As for atmospheric models, used to force ocean models, they also assimilate EO data, notably scatterometer ocean vector winds, SST and significant wave height (e.g., ERA5 reanalysis, Hersbach et al. 2019).

Such integrated systems are the backbone of reanalyses (coherent historical representation of the ocean state over the past decades) and short-term forecasts (up to 10 days) of the physical and biogeochemical ocean states. The outputs can then be used for diverse 
applications related to coastal hazards. A focus on coastal sea level monitoring and forecasting with integrated systems is provided in Sect. 4.1.2.

In addition to constraining the predictions of the numerical models through data assimilation, EO are essential to guide the development and validation of numerical models of the ocean and to constrain the atmospheric conditions that are forcing ocean models.

\section{Monitoring Marine Coastal Hazards}

In this section, EO monitoring of main coastal hazards is discussed.

\subsection{Coastal Erosion and Flooding}

Being at the land-sea boundary, the coastal zone is prone to marine flooding due to the relative change of elevation between the sea level at the coast and the Earth's surface.

\subsubsection{Total Water Level at the Coast}

Relative sea level rise (RSLR, i.e., relative to the ground) and changes at the coast occur on a wide range of spatial and temporal scales, and are due to a complex combination of processes: processes causing sea level changes in the open ocean (e.g., mass addition from ice sheets, mountain glaciers, terrestrial water storage changes and the associated changes in gravitational and Earth rotation effects, steric effect and redistribution of heat, salt and mass by ocean circulations), additional processes causing sea level changes in the coastal ocean (e.g., tides, wave setup, storm surge, river discharges, wind driven upwelling) and vertical land motion in the coastal zone. Monitoring total water level changes at the coast for floods is therefore challenging, as it requires monitoring "offshore" sea level, as close as possible to the coast (Sect. 3.1), as well as ancillary fields that vary over a wide range of temporal and spatial scales: wind waves (Sect. 3.3), surface winds (Sect. 3.4), surface atmospheric pressure, river runoffs (Durand et al. 2019; Longuevergne et al. in review). Empirical formulae could be used to estimate wind-wave contributions to coastal sea level over large spatial scales and long time-scales (e.g., Melet et al. 2018) based on deep water wave characteristics (wave height, period and direction, Sect. 3.3) provided that nearshore bathymetry and beach profiles (Sects. $2.1,2.2$ ) are known, which is presently not the case over most of the coastal areas so that assumptions are needed (Dodet et al. 2019).

As the different processes contributing to total water level at the coast impact the coast differently, evaluating their relative importance is essential to assess the local coastline vulnerability to, e.g., flooding and erosion. However, interactions between these processes can be substantial (e.g., Idier et al. 2019). Monitoring the different relevant metocean variables to separately estimate the contribution from the main processes driving sea level changes at the coast is therefore not entirely satisfactory. Direct measurement of total water level at the coast, including the wind-wave setup and swash, is needed. Video-monitoring could offer possibilities in that regard but an adequate widespread observing system is still lacking.

Finally, in terms of flooding hazards, the sea level that matters is that relative to the land. Vertical land movements, and more specifically land subsidence, cause a relative rise of the mean sea level and have to be accounted for when evaluating coastal impacts (Ingebritsen and Galloway 2014). Coastal land subsidence, of both natural and anthropogenic origin, develops mainly at the local to regional scale. Despite the relatively small extent 
of the coast affected, land subsidence is becoming the dominant contributor to relative sea level rise and one of the main processes threatening low-lying deltaic zones worldwide, i.e., the coastal areas most prone to flooding (e.g., Shirzaei and Bürgmann 2018). Land subsidence in these landforms results from their continuously increasing overexploitation for urban and industrial settlements, crop production, land reclamation, and production of natural resources (e.g., hydrocarbons).

The measurements carried out over the last two decades by SAR interferometry show that land subsidence has caused in several deltas a loss of land elevation up to several tens of $\mathrm{mm} / \mathrm{yr}$, i.e., an amount much larger than the absolute sea level rise observed over the last decades. A few representative examples are provided in Fig. 7. The figure compares the sea level change observed by satellite altimetry from 1992 to 2014 with the vertical land motion in different deltas that are densely populated and characterized by a low elevation relative to the mean sea level.

SAR interferometry provides detailed maps of the vertical land motion (Sect. 2.3) and shows that the process is characterized by a significant heterogeneity that must be properly accounted for when past evolution of coastal zone is reconstructed (e.g., Corbau et al. 2019) and flooding scenarios in the future decades are developed (e.g., Shirzaei and Bürgmann 2018).

The subsurface fluid-pressure decline caused by pumping of groundwater is the main driver of land subsidence in coastal regions (e.g., $\mathrm{Ng}$ et al. 2012; Chaussard et al. 2013; Raucoules et al. 2013). However, natural processes, such as tectonics, glacial and sediment isostatic adjustment, natural compaction, and other anthropogenic activities like hydrocarbon production from deep reservoirs, land reclamation, marshlands drainage and conversion to farmlands, conversion of prime agricultural areas into residential and industrial, massive construction, reduction of sediment availability due to river damming and mining superpose to produce the observed displacements (e.g., Tosi et al. 2009; Ng et al. 2012). The simultaneous occurrence of processes characterized by different temporal and areal scale, together with the intrinsic heterogeneity of the hydro-geo-mechanical properties of the subsurface, explains the rationale of observed displacement variability.

Disentangling the various processes is of paramount importance. Understanding which are the main anthropogenic factors contributing to land subsidence allows defining, planning, and possibly implementing counter-measures to arrest or decrease it (e.g., Ingebritsen and Galloway 2014) and, consequently, reduce flooding hazard in coastal communities. This requires the use of specific numerical models (e.g., Zanello et al. 2011; Ye et al. 2016; Zoccarato et al. 2018) and the integration of remotely sensed information with in situ measurements provided, for example, by borehole extensometers, geotechnical lab tests on soil samples, piezometric records, geophysical logs, and sedimentation-erosion tables.

\subsubsection{Monitoring and Forecasting Sea Level with Integrated Systems}

As coastal sea level is both locally and remotely forced, dynamical downscaling of numerical ocean operational models is usually implemented to forecast sea level with a leadtime of a few days to a season (Wilandsky et al. 2017): coastal ocean forecasting systems (COFS, De Mey-Frémaux et al. 2019) are embedded in wider-area, coarser resolution regional operational forecasting systems (Sect. 3.7). COFS have to represent the coastal ocean continuum, from the open ocean, to shelf areas and estuaries or deltas. Coastal flooding primarily occurs during extreme sea level events, which are already more frequent (Menendez and Woodworth 2010) and are projected to become even more so in response to 


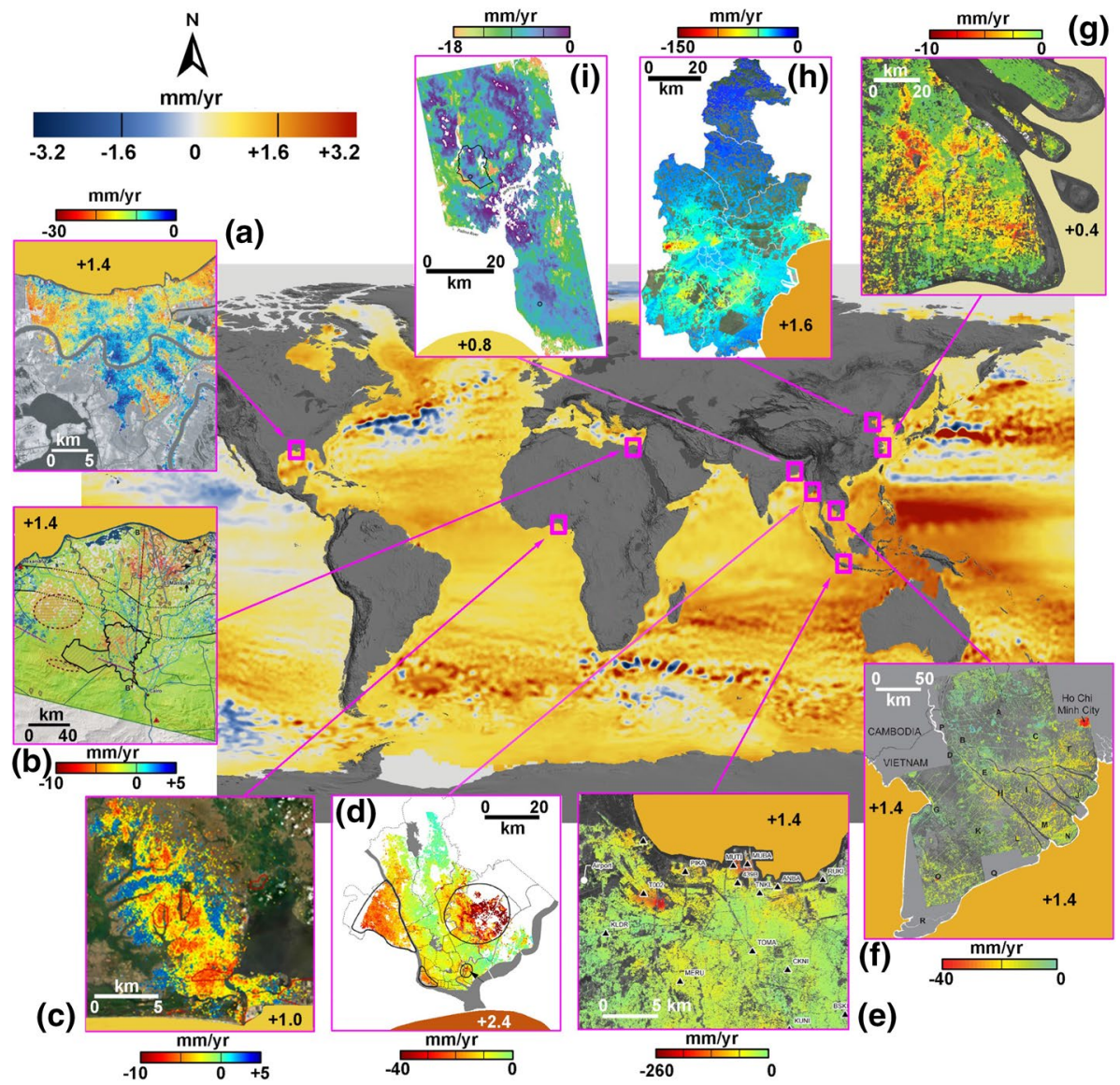

Fig. 7 Base map: total sea level change (in mm/yr) between 1992 and 2014, based on data collected from the TOPEX/Poseidon, Jason-1 and Jason-2 satellites. Blue regions are where sea level has gone down, and orange/red regions are where sea level has gone up (after NASA's Scientific Visualization Studio, https ://svs.gsfc.nasa.gov/4345). Insets a-i: vertical land motion (land subsidence is negative) detected by SAR interferometry in representative low-lying coastal regions: a New Orleans, USA (after Dixon et al. 2006); b Nile delta, Egypt (after Gebremichael et al. 2018); c Lagos, Nigeria (after Cian et al. 2019); d Yangon city, Myanmar (after van der Horst et al. 2018); e Jakarta, Indonesia (after Ng et al. 2012); f Mekong delta, Vietnam (after Erban et al. 2014); g Yangtze delta, China (after Yang et al. 2013); h Tianjin, China (after Zhang et al. 2016); and i Ganges-Bramaputra delta, Bangladesh (after Higgins et al. 2014). In each subpanel the sea level change in front of the coastline as quantified in the global map is provided for comparison

climate change (Vousdoukas et al. 2018). As extreme sea levels can be caused by the combination of different processes (Sect. 4.1.1), the regional and coastal forecasting systems should be as consistent as possible in terms of represented physical processes. The substantial interactions between the aforementioned processes (e.g., Idier et al. 2019), especially during extreme events, also advocates for coupled forecasting systems. These are under development for regional operational models (e.g., Staneva et al. 2016; Sotillo et al. 2019).

Satellite observations such as sea surface height for sea level (Sect. 3.1) and SST (Sect. 3.2) are routinely assimilated in most regional operational systems (Le Traon et al. 2019). Observing system evaluations (OSEs) have shown, in particular, the major 
contribution of satellite altimetry in constraining operational models and assimilating systems (e.g., Hamon et al. 2019). An accurate knowledge of the mean dynamic topography (MDT) is key for assimilating altimetric sea level in ocean forecasting systems (Le Traon et al. 2017). MDT can be inferred from the combination of altimetric and gravimetric (GOCE, GRACE missions) satellite data and in situ observations (e.g., Rio et al. 2014). Yet, MDT remains less accurate in the coastal ocean due to larger errors in altimetric data in coastal areas (Sect. 3.1) and to the scarcity of in situ data upon which scales smaller than $100 \mathrm{~km}$ are constrained in MDT estimates.

Given the complex combination and interactions of processes driving extreme sea levels, the short spatial scales and high-frequency nature of coastal zone evolution, forecasting total water level changes at the coast on spatial and temporal scales relevant for coastal zone management remains, however, challenging (Ponte et al. 2019).

\subsubsection{From Total Water Level to Flooding}

Flooding in low-lying areas can take place due to the following processes: (1) overflow, which is a flooding process during which extreme water levels exceed the heights of coastal natural or artificial defences; (2) overtopping, which occurs when extreme water levels do not exceed the height of coastal defences, and flooding occurs intermittently due to the effects of waves; (3) breaching of coastal defences or erosion of coastal dunes. Ultimately, water flows within the inundated area can accumulate in the lowest areas and the flooding can be enhanced by rain and groundwater. Today, these processes can be modeled accurately, provided that accurate bathymetry, topography (Sects. 2.1, 2.2), wind fields (Sect. 3.4) and land cover (Sect. 2.4) are available (USACE 1996; IGOS 2006; Bates et al. 2005; Le Roy et al. 2015; Ablain et al. 2016). Flooded areas can be monitored via satellite imagery (e.g., SAR data; Twele et al. 2016), and other relevant observations include for example the timing of the flood event, extreme water levels at gauges and along walls in the flooded area. Furthermore, while this article addresses coastal hazards, it can be noted that observations of damages after events are relevant as well, in particular because current flood vulnerability functions are highly uncertain and would deserve further calibration (e.g., Hallegatte et al. 2013; André et al. 2013; Hinkel et al. 2014).

Flooding hazards are leading to increased risks as the exposure of population and assets in the coastal zone are growing, sea level is rising in response to climate change, and high subsidence rates in many densely populated areas (e.g., Hallegatte et al. 2013; McGranahan et al. 2007; Neumann et al. 2015).

In addition to floods, relative sea level changes in the coastal ocean can have diverse adverse impacts such as salinization of aquifers, unsafe harbour operations, loss of coastal wetlands (e.g., salt marshes, mangroves), and degradation of ecosystems.

\subsection{Shoreline Changes}

While erosion and shoreline changes are often used interchangeably, they actually have different meanings (Le Cozannet et al. 2014). Erosion can be defined as a process involving morphological changes such as sediment transport or abrasion of rocks; shoreline changes commonly refer to the motion of a particular shoreline indicator, such as the base or the top of a dune or cliff, or the mean or high water lines on a beach 
(Boak and Turner 2005). Hence, depending on the shoreline change proxy considered, coastal erosion may not necessarily result in shoreline changes.

Shoreline changes are typically monitored using a combination of in situ and remote sensing data, including historical charts and photographs, aerial photography, beach surveys (e.g., using GNSS or video imagery), and satellite images (Boak and Turner 2005). The manual and semi-automatic handling of such data within geographic information systems is extremely time consuming, so that automated shoreline detection algorithms using satellite images are receiving much attention. Where the shoreline evolves rapidly (i.e., more than $10 \mathrm{~m}$ between two acquisitions), these algorithms have demonstrated their capacity to quantify land area changes, such as in large deltas in South-East Asia (e.g., Shearman et al. 2013). However, most shorelines are currently evolving at rates not exceeding $1 \mathrm{~m} /$ year (Bird 1987). Reaching such accuracy is quite demanding, although promising results have been recently obtained by applying automated shoreline detection algorithms to the Google high-horizontal resolution imagery database (Luijendijk et al. 2018; Mentaschi et al. 2018; Fig. 5c).

Shoreline changes involve processes acting at multiple timescales ranging from multicentennial to extreme events (Ranasinghe 2016). The related hazards are generally seen as a threat to infrastructures and their stability and sometimes to coastal ecosystems. The associated prevention measures involve protecting the shorelines by means of hard or soft engineering (e.g., dikes, groins, sand nourishment), but may also require relocating assets such as buildings or transport infrastructures. There are two critical challenges associated with managing shoreline changes hazards today (Wong et al. 2014): first, shoreline retreat is now perceived as an increasing threat since it affects a number of urbanized beaches and cliffs; second, climate change and sea level rise will favor shoreline retreat over the twentyfirst century and beyond, to an extent that remains largely unknown today.

Recent research in shoreline change monitoring has significantly improved the contribution of satellite remote sensing to managing shorelines and understanding the ongoing processes. First, recent global assessments of ongoing shoreline changes have confirmed the current paradigm that human intervention are the most obvious cause of observed shoreline changes worldwide (Mentaschi et al. 2018). Second, while sea level rise impacts on shoreline changes remain undetectable in most temperate and tropical areas (Cramer et al. 2014; Duvat 2019), early signs of transition toward shoreline changes are displayed in some coastal sites, which in some cases are suspected to be due to subsidence or to combined effects of sea level rise and waves (Albert et al. 2016; Garcin et al. 2016; Oppenheimer et al. 2019). This improved understanding of the current status of world's shorelines is based on a combination of field work and the analysis of aerial photographs and satellite images. Over the coming decades, breakthroughs in the area of shoreline change monitoring is expected to take place with the automatization of shoreline feature detection procedures. Furthermore, as accelerating sea level rise (Ablain et al. 2019; Oppenheimer et al. 2019) will favor coastal erosion, observations will be key to validate shoreline evolution models, which are still subject to large uncertainties (Toimil et al. 2020).

\subsection{Maritime Security Hazards}

Different human activities are conducted at sea, such as shipping, fishing, drilling, or production of marine energy (Fig. 5d-h).

Global trade is mostly conducted by shipping at sea, representing more than $80 \%$ of trade volume (UNCTAD 2017). Shipping lanes are becoming busier, and are dense in 


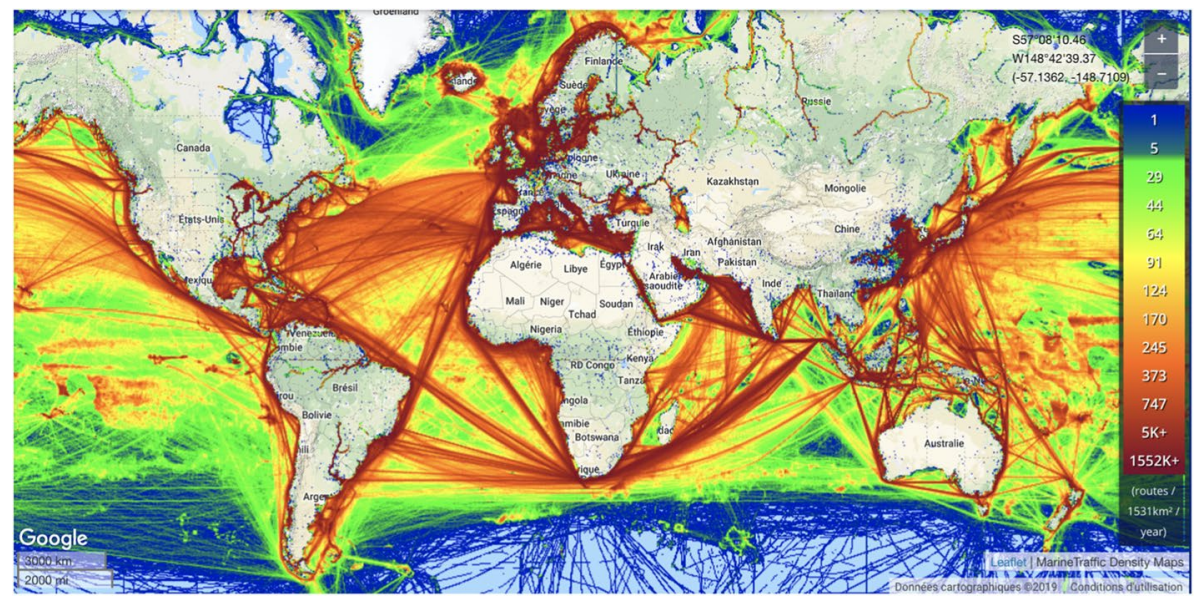

Fig. 8 2016-2017 density map of vessels. Map extracted from www.marinetraffic.com

coastal zones (Figs. 5d, 8). Industrial fishing occurs in more than 55\% of the ocean area, with a spatial extent corresponding to more than four times that of agriculture (Kroodsma et al. 2018, Fig. 9).

Hazards related to shipping and fishing include accidental spills or operational discharges of oil and chemicals, dumping of waste (e.g., Liubartseva et al. 2018), and accidents (Fig. 1). Such hazards are rather concentrated in busy shipping lanes and ports (Figs. 8, 9), and are therefore affecting the coastal zone.

Accidents at sea can be induced by humans, but also by natural hazards such as largeamplitude or steep wave and sea-ice conditions. For instance, twenty-two super-carriers sunk due to collisions with rogue waves over the 1969-1994 period in the Pacific and Atlantic oceans, causing 525 fatalities (Kharif and Pelinovsky 2003). Accidents at sea are triggering search and rescue operations during which a search area has first to be determined, with the majority of rescue cases taking place less than $40 \mathrm{~km}$ from the shore (Breivik and Allen 2008).

The last known position of the vessel is an essential element to determine a search area. Different regulations require particular classes of vessels to be equipped with ship-borne transponders to transmit their identity and position at repeated intervals. Such tracking systems include the Automatic Identification System (AIS, IMO 2000), Long-Range Identification and Tracking (IMO 2006) and Vessel Monitoring System (FAO 1998). Although such tracking systems provide a surge of information (e.g., 22 billion AIS messages corresponding to more than 70,000 industrial fishing vessels where processed from 2012 to 2016 in Kroodsma et al. 2018), they do not provide a comprehensive detection of vessels (e.g., unidentified and noncooperative ones). EO such as satellite-borne SAR data (e.g., Sentinel-1; Fig. 10; Greidanus et al. 2017; Santamaria et al. 2017) and optical satellite imagery have thus become essential to detect vessels (see a review by Kanjir et al. 2018). Yet, in the coastal zone, SAR-based ship detection is more prone to false alarms arising from azimuth ambiguities (re-occurrence of a target at a determined distance from the original target stemming from the pulse repetition frequency of the data sampling) due to the potential presence of strong reflectors on land and to low wind conditions in the coastal zone (e.g., Velotto et al. 2014; Fig. 10). Recently, the potential of ship detection by the Sentinel-5P Tropomi instrument (a high-resolution, 


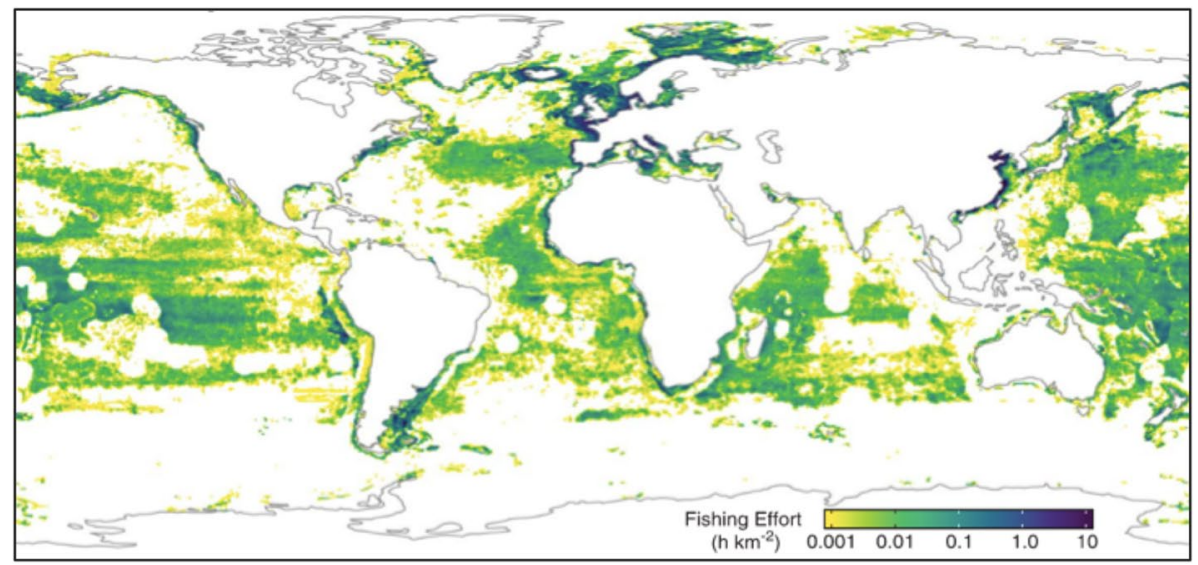

Fig. 9 Total fishing effort [hours fished per square kilometer $\left(\mathrm{h} \mathrm{km}^{-2}\right)$ ] in 2016 by all vessels with AIS systems. Adapted from Kroodsma et al. (2018)

advanced multispectral imaging spectrometer), through their emission of nitrogen dioxide, has been highlighted. Yet, as the drift of an object lost at sea depends on its drift properties (notably the shape of the object), identifying the vessel type and size together with their position is also of importance. This is more challenging as it requires high-resolution satellite images to estimate different characteristics of the vessel. Monitoring fishing fleets' activity in particular could also support a sustainable use of the ocean by reducing overfishing and associated hazards of reduction of food production and biodiversity, and impairment of ecosystems functioning (UN 2015).

An object lost at sea is subject to drift forced by surface currents and drift predicted from leeway, the latter being defined in Breivik et al. (2013) as the motion of the object induced by wind (10 m reference height) and waves relative to the ambient current (between 0.3 and 1.0 $m$ depth). Search and rescue operations therefore largely rely on Lagrangian pathways calculations, which depend on near-real time information on surface winds (Sect. 3.4), ocean surface currents (Sect. 3.5) and waves (Sect. 3.3) (van Sebille et al. 2017), with high spatiotemporal resolution. Indeed, the pathways are sensitive to currents on scales from meters to kilometers (e.g., D'Asaro et al. 2018). EO and/or their integration in operational models (Sect. 3.7) therefore provide essential information for the transport of objects lost at sea.

\subsection{Maritime Pollution}

\subsubsection{Oil, HNS Spills, Plastics}

Ships are transporting different substances such as oil and harmful and noxious substances (HNS) that, if spilled in the ocean, can create hazards to marine flora, fauna and/or human health, can interfere with other legitimate uses of the sea (tourism, fisheries, navigation) and can result in environmental damages. More than 2000 different HNS are regularly transported by sea, including acids, liquefied natural and petroleum gases, ammonia, benzene, palm and vegetable oils. Spills can occur from ships due to sinking, grounding or cracking, notably under bad weather conditions; from incidents on-board ships (e.g., fire, mechanical failure, human error); or from port installations. The Cedre database (http:// 


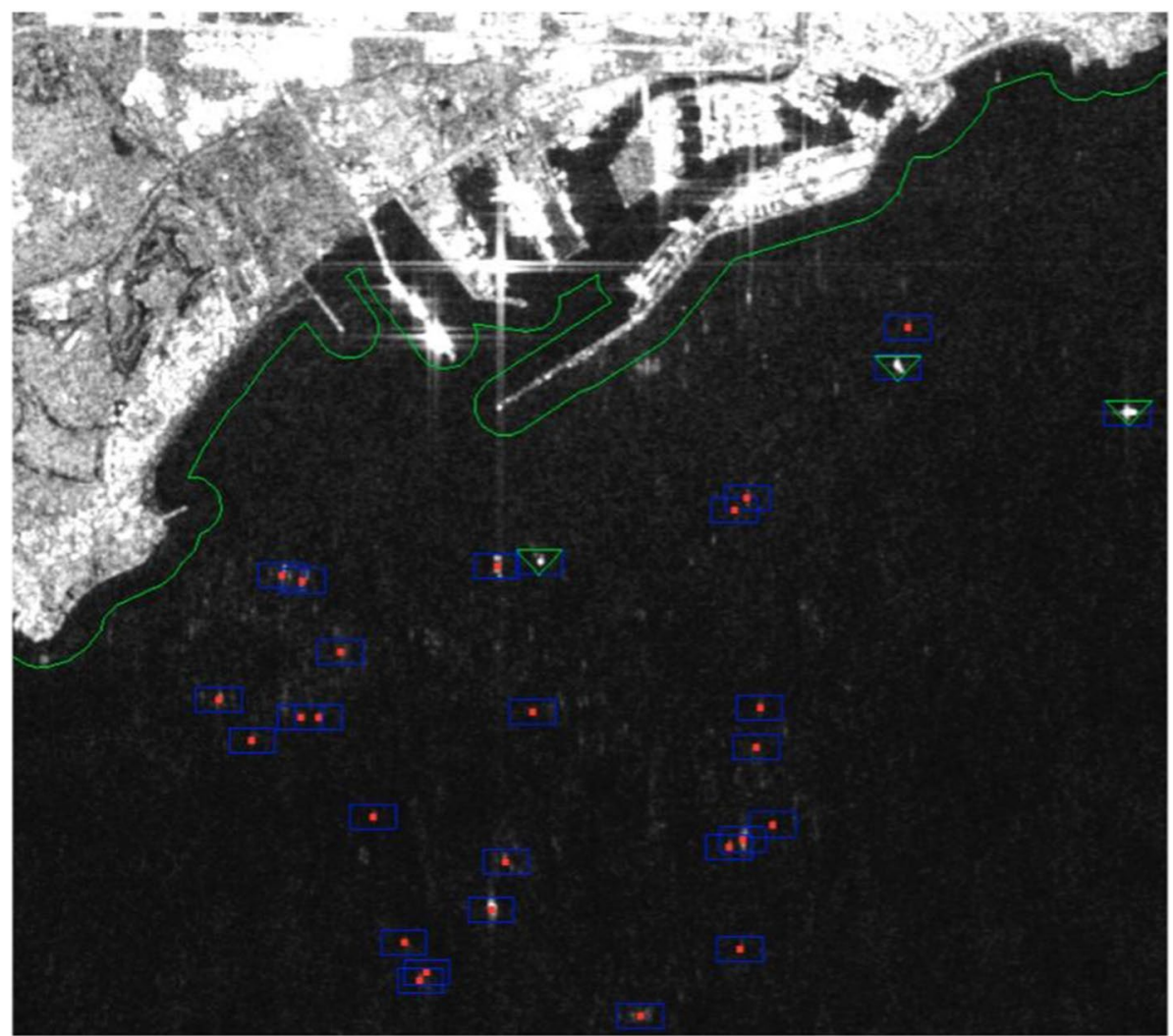

Fig. 10 An example of ship detection with Sentinel-1, offshore Taragona's port (Spain). The green line shows the land/sea mask used by the detection algorithm. Echoes (bright spots in the image) on the ocean are mostly due to azimuth ambiguities from bright reflectors on land. Spots that were bright enough were detected by the detection algorithms (blue rectangles and green triangles). Red dots indicate targets that were automatically recognized as azimuth ambiguities. The only three real targets (green triangles) correspond to a buoy (at the image center) and to two ships (top right). From Greidanus et al. (2017)

wwZ.cedre.fr) on spill incidents gives a median annual number of 29 spill incidents (with a volume $>10 \mathrm{~m}^{3}$ ) over 2004-2013. For years 2013-2015, the total spill volume of 89,000 tons was distributed with $25 \%$ in offshore, $66 \%$ in inshore, $1 \%$ in estuaries and $8 \%$ in ports incidents. Spill incidents for HNS are less frequent than for oil. Despite increasing oil shipping over the last 50 years (e.g., from 1500 to more than 3000 million metric tons from 1970 to 2018, source: UNCTADStat), oil spill incidents have drastically decreased (with an average of nearly 80 spill incidents per year in the 1970s to 6 in the 2010s, source: ITOPF Oil Tanker Spill Statistics 2019). Once spilled, oil and HNS can evaporate, be dissolved, float or sink, depending on their properties.

Another source of pollution comes from marine debris. Plastics account for $80 \%$ of marine debris and cause environmental as well as health hazards (i.e., ingestion, harm to marine life, invasive marine bacteria or organisms that can disrupt ecosystems). Marine plastic sources are mostly land-based (i.e., runoff, sewer overflows, coastal tourism, industrial activities, paints, tyre dust; Jambeck et al. 2015) but marine-based sources (e.g., fishing and shipping litter, aquaculture) are not negligible. Only a small fraction of plastic litter 
floats close to the ocean surface. Most of plastic is fragmented into micro or nanoplastics through the action of solar radiation and marine conditions (wind, currents), sink in the ocean, is ingested by fishes or marine mammals, which represent a hazard for their health (e.g., Guerrini et al. 2019) or ends up on beaches (van Sebille et al. 2020).

As for search and rescue activities (Sect. 4.3), information on the sources of pollutants and marine debris, on the near surface wind, currents, and waves are crucial to perform Lagrangian calculations of their pathways (e.g., van Sebille et al. 2017; Maes et al. 2018). Additional properties for oil spill pathway modeling are needed, such as turbulent diffusivities or absorption by the coastal environment (De Dominicis et al. 2013).

EO can directly monitor oil spills thanks to the different emissivity, reflectance of water and oil (optical sensors), and to the reduction of the sea surface roughness induced by oil films (the oil dampens capillary waves generated by the winds on the ocean surface, that define sea surface roughness, Sect. 3.4), leading to changes in backscattering and brightness on SAR data under favorable metocean conditions (excluding low wind conditions). Visible, infrared, microwave and radar sensors such as spectroradiometers (e.g., AquaMODIS, Terra-MISR), spectrometers (ENVISAT-MERIS), multispectral radiometers (Sentinel-2) have thus been used to monitor oil spills, but SAR sensors have been primarily used (see a review on remote sensing of oil spill by Fingas and Brown 2018). An illustration of oil spill monitoring with SAR on-board Sentinel-1 is given on Fig. 11.

For more information on marine pollution and its monitoring from space, the reader is referred to Viatte et al. (2020).

\subsubsection{Underwater Noise}

The ocean is not quite a silent world. Water transmits sound efficiently and different natural sources of sound (breaking surface waves, rain, thunder, sediment movement, earthquakes or marine life, etc.) fill the ocean to create an ambient noise. Many marine species critically use sounds to navigate, communicate, find prey or reproduce. Yet, oceans are becoming noisier due to additional sources of noise induced by human activities such as shipping, use of sonar, pile driving, seismic surveys used to map the geological structure beneath the seabed for research or commercial purposes (e.g., prior to coastal construction, Fig. 5f), offshore marine energy development (wind farms, wave, tidal or current energy) (Fig. 5g-h), oil and gas exploration and operations, etc. Recreational shipping and industrial activities are particularly dense in coastal waters (Figs. 5, 8).

Anthropogenic underwater noise can induce adverse effects on marine life (Hildebrand 2005), although understanding and quantifying these impacts remains challenging (e.g., Popper and Hastings 2009; Slabbekoorn et al. 2010; Hawkins and Popper 2017). Effects depend on the noise intensity, duration and frequency, on marine animal characteristics (such as specie, sex, age) and range from temporary or permanent hearing impairment, displacement to quieter areas (which could lead animals to non-suitable ecosystems), acoustic masking (which could reduce ability to catch preys and communicate-including with offspring), increased stress levels, and can lead to the animal death. Underwater noise pollution has consequently been a growing concern and regulations are emerging at national (Merchant et al. 2016) and international levels (e.g., UN 2018; European Commission 2008-MSFD descriptor 11). As a result, noise mitigation and abatement recommendations and policies are also being created (e.g., Merchant 2019).

While EO cannot be used to directly assess underwater sound and related ecological impacts, they are beneficial for modeling and forecasting underwater noise propagation and 


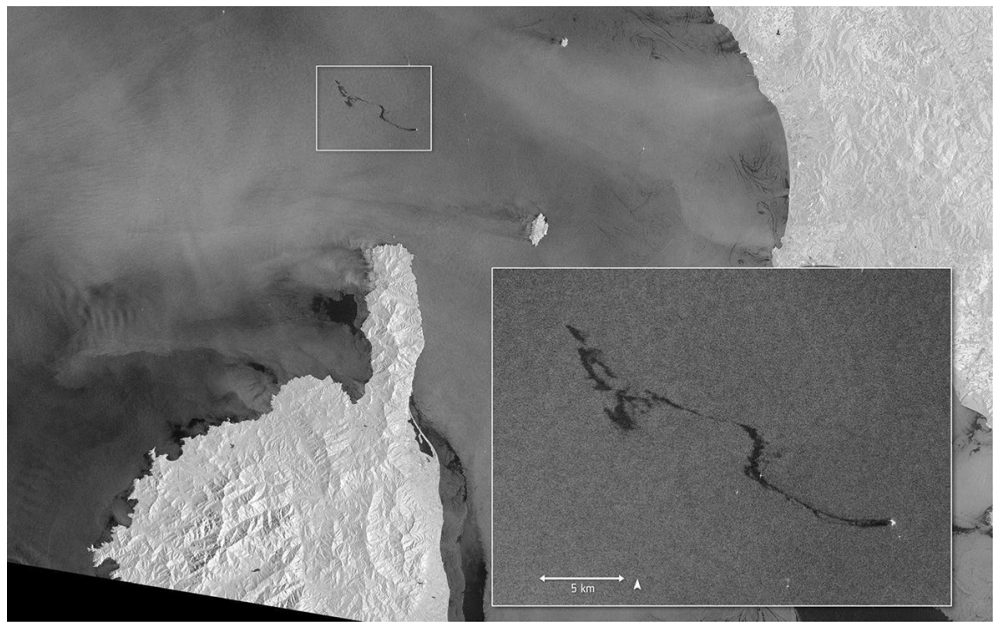

Fig. 11 Monitoring of an oil slick (dark area in the white rectangles) by Sentinel-1. The slick occurred after a collision between two merchant ships in the Mediterranean Sea on October 7, 2018. Credit: contains modified Copernicus Sentinel data (2018), processed by ESA, CC BY-SA 3.0 IGO

marine life exposure (e.g., Farcas et al. 2016; Roberts et al. 2016). Indeed, the propagation of sound is influenced by the $3 \mathrm{D}$ water density (i.e., temperature, salinity), which can be modeled and forecasted using operational ocean numerical models that assimilate satellite data (in particular satellite altimetry) (Sect. 3.7), and bathymetry, which can be derived by satellite (Sect. 2.1). Sources of noise can be inferred from maritime surveillance (AIS and SAR imagery, Sect. 4.3) and environmental data (e.g., for sea state, wind, Sects. 3.3 and 3.4). Maps of marine animal distribution data needed to estimate marine life exposure to noise can be inferred based on candidate covariates (Fig. 11). For instance, Roberts et al. 2016 used (i) physical oceanographic covariates such as SST, distance to SST fronts, wind speed, total and eddy kinetic energies, and distance to geostrophic eddies derived from sea surface height observations, and (ii) biological covariates such as chlorophyll concentration, primary production, and potential biomass and production of zooplankton and epipelagic micronekton. Most of these covariates were derived from satellite observations.

\subsection{Water Quality}

Although they represent only $7 \%$ of the total ocean surface, coastal and inland water zones produce up to $40 \%$ of the marine and freshwater biomasses inventoried today and $85 \%$ of the marine and freshwater resources exploited by humans. Moreover, inland waters provide key ecosystem services with direct linkages to human health (IOCCG 2018). Therefore, it is vital to study these waters in a systematic way and with a long-term perspective to characterize the variability of biogeochemical properties and to understand their impacts on the water quality. The EU Marine Strategy Framework Directive (MSFD) which is complementary to the European Water Framework Directive (WFD), concerning waters in estuarine transitional areas and very close to the coast, introduces the concept of "European waters" with the aim of reaching a good ecological state of the marine environment in its entirety, and the improvement of marine biodiversity conservation. Reaching this goal 
requires a global framework for coordinating state-members including a substantial effort in observations and surveys of waters to establish environmental baselines allowing us to understand ongoing and future developments in water quality.

The deterioration of surface water quality by contaminants, nutrients, excess heat, and other factors (Fig. 1) is arguably the greatest threat to future healthy water availability. Health studies show that water-related illnesses are a major global problem. Clearly suitable water quality is critical to sustaining life on our planet. The UN Millennium 2015 Goals highlight the importance of accessible freshwater and sanitation for human health. Clean water is critical not only to human health, but to overall ecosystem health. Monitoring and detecting change is critical for the protection of biodiversity in natural areas (e.g., Natura $2000^{1}$ ).

The monitoring of the water quality can be obtained by using ocean optics or ocean color radiometry (OCR), as described in Sect. 3.6 and recently reviewed in Chawla et al. (2020). Examples of the use of OCR to monitor water quality are provided in IOCCG (2018). Here we describe two examples over Vietnamese coastal waters (Loisel et al. 2014, 2017). These studies aimed at analyzing the spatiotemporal variability of the chlorophylla concentration and suspended particulate matter over Vietnamese coastal waters and Mekong delta respectively, using the MERIS archive between 2002 and 2012. The time series were decomposed into three terms (seasonal, trend, irregular term) and analyzed with regard to regional oceanographic and hydrologic conditions. The chlorophyll-a concentration showed a long-term monotonic trend from 2 to $>5 \% \mathrm{yr}^{-1}$ in different coastal areas where aquaculture activities exhibited an increase in production weight (from 31 to $113 \%$ ). For the Mekong delta, the suspended particulate matter concentration showed a long-term trend of about $-5 \% \mathrm{yr}^{-1}$ in the pro-delta area. This decreasing trend was linked to the decrease of the Mekong river sediment output during the high flow season. These studies show the interest of EO for surveying the changes in biogeochemical parameters that are proxies of water quality and to link their variabilities to physical forcings that are also obtained from EO. It highlights the interest of synergistic use of different EO observations to understand the variability of water quality in coastal zones.

\subsection{Marine Ecosystems Shifts}

Although not as evident as flooding or hurricanes, ecological shifts may be considered hazards, albeit of a subtle type. Ecological shifts—also known as regime shifts, critical or catastrophic transitions, phase shifts, abrupt shifts-are sudden, dramatic and persistent changes in the structure and function of an ecosystem. They signify a profound restructuring of the trophic web, often into a novel, or alternative state, difficult to reverse because of changes in the ecosystem internal feedback mechanisms. As a result, they often impact the ecosystem services, i.e., the benefits human populations obtain from ecosystems, and can disrupt economies and societies (Scheffer et al. 2001; Scheffer and Carpenter 2003; Scheffer 2009; Biggs et al. 2012; Conversi et al. 2015; Möllmann et al. 2015; Lauerburg et al. 2020; Swingedouw et al. in review).

Coastal marine habitats (beaches, salt-marshes and ponds, mangroves, estuaries, deltas and intertidal habitats, seagrass beds, kelp forests, coral reefs, salt-marshes and ponds, semi-enclosed seas) are degrading in many places (Hoegh-Guldberg et al. 2014).

\footnotetext{
${ }^{1}$ https://ec.europa.eu/environment/nature/natura2000/.
} 
Ecological shifts have been found in all habitats where decadal time series exist (Moellmann et al. 2011, 2015; Beaugrand et al. 2015; Gattuso et al. 2015). While the history of life reveals repeated planetary-scale tipping points, the risk of additional, possibly multiple, transitions is increasing (Hughes et al. 2013; Rocha et al. 2018; Steffen et al. 2018; Lenton et al. 2019). As combined human actions are now simultaneously increasing global temperatures and decreasing biodiversity, threatening 1 million species with extinction (https ://www.un.org/sustainabledevelopment/blog/2019/05/nature-decline-unprecedented-repor t/; IPBES 2019), we can reasonably expect more social-ecological regime shifts in the near future. We therefore need to use all available tools to monitor and forecast them. We discuss below how EO can help monitor and protect coastal ecosystems, and contribute to ecosystem shift early detection, by focusing on three examples: coral reefs, coastal marshes and pelagic ecosystems.

\subsubsection{Coral Reefs}

Coral reefs are some of the most biodiverse habitats of this planet, providing shelter to $25 \%$ of all fish species. However, in the last decades many coral reefs around the globe have shifted from the coral state to an alternate state of fleshy algae, from which recovery is rare (Hughes 1994; Bellwood et al. 2004). Bleaching occurs when waters are too warm and corals expel their symbiotic algae and turn white, and can be reversed if the warm period is short. Starting in the 1980s, mass bleaching phenomena have co-occurred around the globe, indicating the common warming stressor. Coral reefs are currently under multiple stress (ocean warming, acidification, local predators and diseases) in several locations worldwide, including the Great Barrier Reef (Bellwood et al. 2004, 2019; Normille 2016; Hughes et al. 2017). At the current rate of warming and associated predicted increases in marine heat waves (Oliver et al. 2019), it is under debate whether coral reefs will become extinct by the end of this century (Matz et al. 2018).

In the case of coral reefs, satellites have already contributed essential information for understanding some mechanisms, and they continue to monitor reef extension and to provide forecasts of the risk of bleaching (Nim et al. 2010; Kamenos and Hennige 2018). For example, analysis of the global satellite SST data (Sect. 3.2) has indicated the relative change in cool versus warm days: over 1985-2012 the warm-temperature periods have increased while the cool-temperature periods (which carry potential for reef recovery) have decreased (Heron et al. 2016). This information is essential for evaluating the risk of norecovery. Global observation programs, such as the NOAA Coral Reef Watch, currently provide near-real-time satellite SST data and algorithms for monitoring thermal stress risk (Fig. 12).

\subsubsection{Coastal Marshes}

As human impacts grow and sea level rises, coastal marshes can become endangered. The Wadden Sea provides an emblematic example of this threat. This coastal strip located offshore The Netherlands, Germany and Denmark is the largest unbroken tidal flat area of the temperate world. It provides shelter and feeding grounds for numerous species and food provisions in this area are 10-20 times higher than in adjacent deeper waters (Reise et al. 2010). Because of its unique characteristics, it has been designed a UNESCO World Heritage Site (https://whc.unesco.org/en/list/1314/). Over time, human impacts (habitat destruction, overexploitation, pollution, sand extraction, climate change and associated sea level 


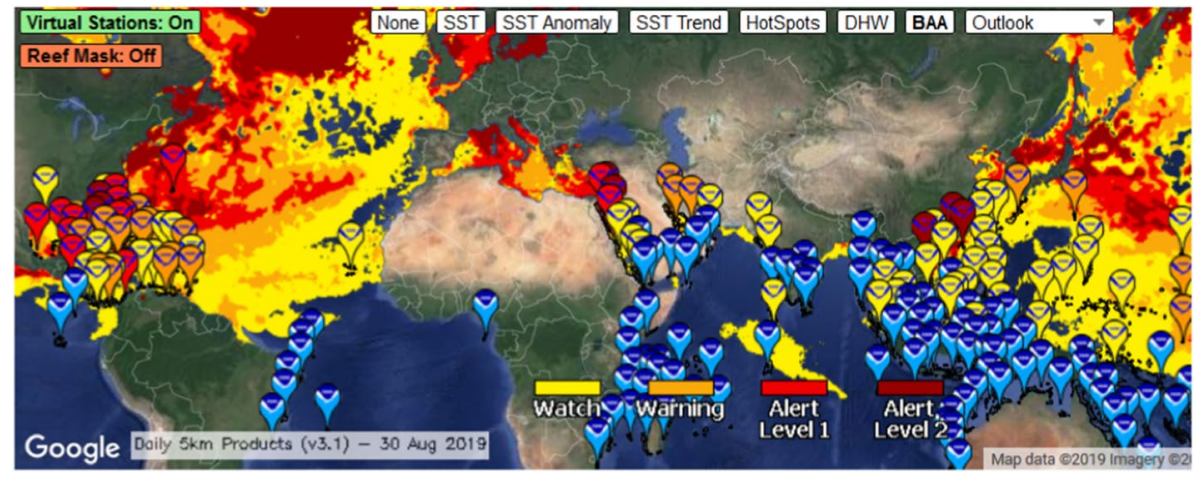

Fig. 12 Example of Bleaching Alert Area map- $5 \mathrm{~km}$ Regional Virtual Stations, providing high resolution information on a global scale. From NOAA Coral Reef Watch, 2019, updated daily. NOAA Coral Reef Watch Version 3.1 Daily Global $5 \mathrm{~km}$ Satellite Coral Bleaching Heat Stress Alert Area Product overlaid on the Daily $5 \mathrm{~km}$ Satellite Regional Virtual Stations Map, Aug. 30, 2019. College Park, Maryland, USA: NOAA Coral Reef Watch. Data set accessed 30-Aug-2019 at https://coralreefwatch.noaa.gov/vs/map.php)

rise) have profoundly modified this ecosystem (Lotze et al. 2005; Eriksson et al. 2010). In particular, ecosystem regime shifts occurred in this sea in 1979 and 1988 (Weijerman et al. 2005; de Young et al. 2008; Conversi et al. 2010).

EO can provide essential large-scale (spatial) and continuous (temporal) information for monitoring and early detection of changes in coastal wetlands. For example, Copernicus Sentinel satellites images have been used to identify areas with mollusc abundance in the Wadden Sea (NEREUS/ESA/EC 2018). Copernicus Sentinel-1,2 and Sentinel-3 are currently providing data (on erosion and shoreline, and ocean color, respectively) for 3D assimilative models targeted to understanding shifting trends in this area (https://www. ecopotential-project.eu/).

\subsubsection{Pelagic Ecosystems}

Pelagic ecosystem shifts are more complex to investigate, as they do not pertain to fixed locations. While phytoplankton abundance has been monitored for decades via OCR using ocean color as a proxy for its abundance (Sect. 3.6), animal detection is more difficultzooplankton is transparent and nekton is often well below the surface.

However, EO of proxies related to animal abundance can greatly extend the limits of in situ observations over the global ocean. For instance, global temperature data have been used in conjunction with the species thermal ecological niches to predict abrupt shifts (Beaugrand 2015; Beaugrand et al. 2015, 2019) and have shown that, although apparently rare, on a global scale ecological shifts can actually be widespread and ubiquitous (Fig. 13).

While essential, satellite data are currently generally underused by the biodiversity community. Three factors remain essential for a wider usage: continuity, affordability, and access of the data (Turner et al. 2015). For the detection and monitoring of tipping points, another factor is crucial: decadal duration. Indeed, ecological shifts are by definition a transition from one stable state, lasting several years, to another state, and at this scale an abrupt shift lasts a few years. As satellite data collection now spans decades for some 
Fig. 13 Global abrupt shifts occurrences over the period 2010-2014, using species simulations based on METAL theory. Modified from Beaugrand et al. (2019). The color bar shows the percentage of individual species undergoing a significant shift in a given community: $50 \%$ means that half the simulated species exhibited a significant shift, according to the index of abruptness described in Beaugrand et al. (2019)

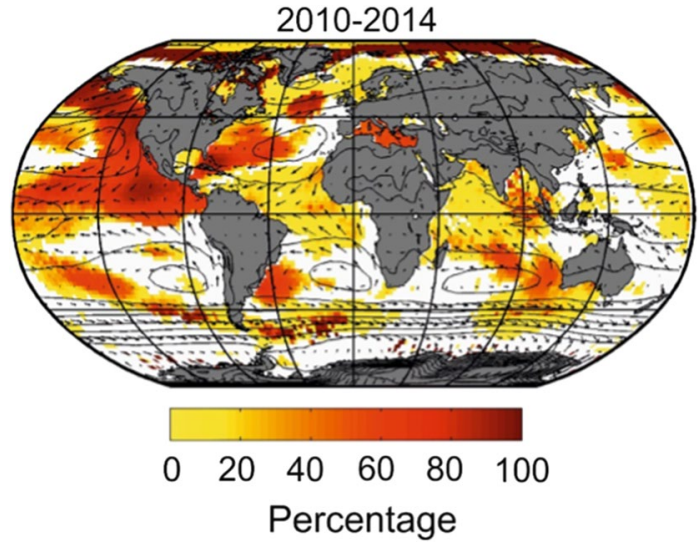

variables, we are confident that it will become increasingly used for ecological shifts detection and early warnings.

\section{Conclusions and Perspectives}

Satellite observations offer great potential for a long-term, synoptic, and rather high-frequency monitoring of the Earth's surface, thanks to a variety of sensors. The use of EO to monitor coastal metocean conditions, coastland hydro-geo-morphological setting, and hazards has significantly developed with the increasing number of satellites with radar sensors. Nowadays, Copernicus is the largest producer of freely and openly available EO data (Sentinels) in the world.

Recently, in the framework of OceanObs'19, numerous community white papers have provided a state of the art of EO of different metocean variables that are relevant for coastal marine hazards. In the present article, we focused on the coastal zone, and more specifically on EO monitoring of drivers of a set of coastal marine hazards, and of the corresponding hazards themselves. In spite of their obvious value, EO are challenged in the coastal zone for different reasons, including:

- Land contamination in the sensor footprint, preventing the retrieval of meaningful data very close to the coast. The size of the footprint determines the size of the land-contaminated area and depends on the sensor technology and frequency.

- Geophysical corrections tend to be less accurate in the coastal zone. For instance, there is a greater variability in atmospheric water vapor, temperature and aerosols in coastal areas than over the open ocean. Absorption and emissivity of these atmospheric components can alter the electromagnetic wave propagation and energy spectrum as received by the satellite-sensor.

In addition, the coastal ocean is a dynamic area, with high spatial and temporal variability, enhanced diurnal variability, and with other processes to be accounted for when compared to the open ocean. These features directly affect the different metocean variables that can be monitored by satellites (SST, SSH, wind, currents, waves, ocean color, etc.), and coastal hazards (e.g., pathways of floating debris and pollutants, dispersal of larvae, marine 
navigation safety, etc.). Coastal hazards can also be highly localized in space and time (e.g., marine floods due to cyclones are lasting $\mathrm{O}(1$ day)). This leads to sampling issues, since catching localized events via along-track observations with a revisit time of several days is unlikely. Coastland geomorphological processes and features (e.g., land subsidence, topography) are generally characterized by a low temporal variability but a significant spatial heterogeneity.

These coastal ocean and hazard specificities guide requirements for future EO missions:

- Higher revisit frequencies (e.g., hourly to daily) to cover more systematically synoptic scales (e.g., using geostationary satellites),

- Higher spatial resolution to observe fine-scale coastal processes,

- Multi-band or multi-frame (e.g., stereo or tri-stereo over tens of seconds) observations to capture rapid evolutions and provide information on wave propagation, surface currents or drifting objects, harmful algal blooms.

A synergetic use of different observations can improve estimates of relevant variables for coastal hazards, as illustrated for surface currents through combined use of altimetric sea level, surface wind and SST observations. In addition, joint observations of coupled air-sea variables such as total surface currents, wind speed and direction, and directional wind-wave spectrum could bring further improvements in coastal ocean monitoring and further insights on various processes. In that respect, several proposals for satellite Doppler oceanography missions have been developed (e.g., SKIM, Ardhuin et al. 2018; WaCM, Rodriguez 2019; SEASTAR, Gommenginger 2019), each one targeting specific processes at different scales (e.g., Villas Bôas et al. 2019). Although these missions are not planned yet, they respond to actual requirements of coastal users.

However, acquiring EO data is not sufficient to monitor hazards in the dynamic coastal zones, which are characterized by shorter-scale variability. To provide relevant information for users, including coastal zone management, a complex added value chain starting from raw EO (satellite, in situ) has to be constructed. First, data have to be processed to provide level-3 or level-4 quality-controlled products. An across-variable, coherent and synoptic spatiotemporal monitoring of the coastal ocean can be reached when EO are assimilated jointly with in situ observations or other remotely sensed observations in operational, numerical models. Such integrated systems are the backbone of metocean condition forecasts in the open and coastal oceans which, by themselves or by backing early warning systems, are essential to reduce exposure to coastal hazards and related risks. Coastal forecasting skills have been shown to increase when near-real time EO are assimilated. They would further benefit from (i) joint observations of different variables, especially in the context of developing more integrated, more coupled operational monitoring and forecasting numerical systems, (ii) a better exploitation of EO by using more types of observations and more effective, potentially coupled data assimilation techniques, but also for model development and validation.

On top of this integrated system layer, additional layers can be added to go towards users. This includes the development of (i) relevant sectoral indicators, assessment and reporting activities, and (ii) service activities, such as user desk, user support and interaction with users to provide products that better address their needs. This is the rationale for the development of EU Copernicus Services, in addition to the Copernicus satellite component (Sentinels). Of particular importance for the monitoring of coastal metocean conditions and hazards are the marine and land services of Copernicus (aka CMEMS and CLMS, respectively). These two complementary services are developing their offer 
for coastal zone users. For instance, CLMS has launched the development of a thematic hotspot product for LCLU in the coastal zone, to capture landscape dynamics at high horizontal resolution over all EU coastal territory (landward distance of $10 \mathrm{~km}$ from the coastline, with 0.5 ha resolution, and more than 60 classes of LCLU that are adapted to the coastal zones). CMEMS is currently providing satellite level-3 and -4 data for the metocean variables addressed here, as well as global and regional reanalyses, nowcasts, and forecasts of the ocean physical (including waves) and biogeochemical states. CMEMS is continuously evolving with more coupled models, increased resolution, improved algorithms to better process satellite observations in the coastal zone, etc. CMEMS will keep evolving in the long-term to monitor and forecast the ocean at finer scales, to improve the monitoring of coastal zones, and to provide a more seamless and better forcing for very-high resolution coastal models (Le Traon et al. 2019). Finer-scale upper-ocean dynamics and surface currents monitoring and forecasting in particular is essential for key hazards such as maritime safety, maritime transport, search and rescue, drift modeling, riverine influence in the coastal environment, pollution monitoring and offshore operations. Yet, regional high-resolution modeling (e.g., (sub)kilometric scale) comes with challenges for the integration of high-resolution satellite (e.g., wide-swath altimetry) and in situ (e.g., HFR) observations. CMEMS and CLMS are also targeting a better dynamic characterization of the coastal zone (Sect. 2) and of river discharges monitoring and forecasting.

Artificial intelligence (AI) brings new perspectives in terms of processing of dense EO datasets in a drastically reduced time, but also in solving complex coastal environmental problems (Shulz et al. 2018) such as monitoring of worldwide coastal sea surface temperature and salinity at high-resolution (Medina-Lopez and Ureña-Fuentes 2019), classification of land use/cover (Aghighi et al. 2014), seagrass distribution in coastal waters (Perez et al. 2018), bathymetry inversion (Danilo and Melgani 2019; Benshila et al. 2020) and sediment transport and morphological evolution (Goldstein et al. 2019). All these methods are now applicable to spatial time series and can be transposed to most of EO satellite sensors when applied to coastal variables. In a more advanced scenario, these techniques can be applied to short-term forecasting such as for early warning systems, or even ENSO event predictions (Ham et al. 2019).

As some marine coastal hazards are becoming more frequent and widespread (e.g., coastal flooding, ecosystem degradation) and will be aggravated by climate changeinduced ocean warming, acidification, deoxygenation, productivity decrease, sustained coastal zone monitoring programs, forecasting and early warning systems will be increasingly needed to reduce risks for the coastal zone environment and population and to guide coastal zone management.

Acknowledgements This article arose from the international workshop on "Natural and man-made hazards monitoring by the Earth Observation missions: current status and scientific gaps" held at the International Space Science Institute (ISSI), Bern, Switzerland, on April 15-18, 2019. The authors are grateful to Anny Cazenave and Teodolina Lopez for taking charge of the implementation of this special issue. The authors thank Thomas Folegot for helpful discussions, and Pierre-Yves Le Traon, Antonio Reppucci and two anonymous reviewers for comments leading to improvements in the manuscript.

Open Access This article is licensed under a Creative Commons Attribution 4.0 International License, which permits use, sharing, adaptation, distribution and reproduction in any medium or format, as long as you give appropriate credit to the original author(s) and the source, provide a link to the Creative Commons licence, and indicate if changes were made. The images or other third party material in this article are included in the article's Creative Commons licence, unless indicated otherwise in a credit line to the material. If material is not included in the article's Creative Commons licence and your intended use is not 
permitted by statutory regulation or exceeds the permitted use, you will need to obtain permission directly from the copyright holder. To view a copy of this licence, visit http://creativecommons.org/licenses/by/4.0/.

\section{References}

Abileah R (2006) Mapping shallow water depth from satellite. In: Proceedings of the ASPRS annual conference, Reno, Nevada, pp 1-7

Ablain M, Becker M, Benveniste J, Cazenave A, Champollion N, Ciccarelli S, Jevrejeva S, Le Cozannet G, Leornardi N, Loisel H, et al (2016) Monitoring the evolution of coastal zones under various forcing factors using space-based observing systems, International Space Science Institute (ISSI) Forum reports. http://www.issibern.ch/forum/costzoneevo/wp-content/uploads/2016/11/ISSI-forum_Coast al_White-paper_18nov2016_Final.pdf. Accessed Aug 2019

Ablain M, Meyssignac B, Zawadzki L, Jugier R, Ribes A, Cazenave A, Picot N (2019) Uncertainty in satellite estimate of global mean sea level changes, trend and acceleration. Earth Syst Sci Data 11:11891202. https://doi.org/10.5194/essd-11-1189-2019

Aghighi H, Trinder J, Lim S, Tarabalka Y (2014) ISPRS annals of the photogrammetry, remote sensing and spatial information sciences. Gottingen 2(8):61-68. https://doi.org/10.5194/isprsannals-II-8-61-2014

Albert S, Leon JX, Grinham AR, Church JA, Gibbes BR, Woodroffe CD (2016) Interactions between sea-level rise and wave exposure on reef island dynamics in the Solomon Islands. Environ Res Lett 11(5):054011. https://doi.org/10.1088/1748-9326/11/5/054011

Almar R, Bergsma EWJ, Maisongrande P, de Almeida LPM (2019) Wave-derived coastal bathymetry from satellite video imagery: a showcase with pleiades persistent mode. Remote Sens Environ 231:111263. https://doi.org/10.1016/J.RSE.2019.111263

Almeida LP, Almar R, Bergsma EWJ, Berthier E, Baptista P, Garel E, Dada OA, Alves B (2019) Deriving high spatial-resolution coastal topography from sub-meter satellite stereo imagery. Remote Sens 11(5):590. https://doi.org/10.3390/rs11050590

Alpers W, Hennings I (1984) A theory of the imaging mechanism of underwater bottom topography by real and synthetic aperture radar. J Geophys Res 89(C6):10529-10546

Alpers WR, Rufenach CL (1979) The effect of orbital motions on synthetic aperture radar imaging of ocean waves. IEEE Trans Antennas Propag 27:685-690

André C, Monfort D, Bouzit M, Vinchon C (2013) Contribution of insurance data to cost assessment of coastal flood damage to residential buildings: insights gained from Johanna (2008) and Xynthia (2010) storm events. Nat Hazards Earth Syst Sci 13(8):2003-2012. https://doi.org/10.5194/nhess $-13-2003-2013$

Antoine D (1998) Apports de la télédétection spatiale de la “couleur de l'océan" à l'océanographie. Océanis 24:81-150

Ardhuin F, Aksenov Y, Benetazzo A, Bertino L, Brandt P, Caubet E et al (2018) Measuring currents, ice drift, and waves from space: the sea surface kinematics multiscale monitoring (SKIM) concept. Ocean Sci 14:337-354. https://doi.org/10.5194/os-2017-65

Ardhuin F, Stopa JE, Chapron B, Collard F, Husson R, Jensen RE, Johannessen J, Mouche A, Passaro M, Quartly GD, Swail V, Young I (2019) Observing sea states. Front Mar Sci 6:124. https://doi. org/10.3389/fmars.2019.00124

Ban Y, Gong P, Giri C (2015) Global land cover mapping using Earth observation satellite data: recent progresses and challenges. ISPRS J Photogramm Remote Sens 103:1-6. https://doi.org/10.1016/j.isprs jprs.2015.01.001

Bates PD, Dawson RJ, Hall JW, Horritt MS, Nicholls RJ, Wicks J, Hassan MAAM (2005) Simplified two-dimensional numerical modelling of coastal flooding and example applications. Coast Eng 52(9):793-810. https://doi.org/10.1016/j.coastaleng.2005.06.001

Beaugrand G (2015) Theoretical basis for predicting climate-induced abrupt shifts in the oceans. Philos Trans R Soc Lond B Biol Sci 370:20130264. https://doi.org/10.1098/rstb.2013.0264

Beaugrand G, Conversi A, Chiba S, Edwards M, Fonda-Umani S, Greene C, Mantua N, Otto SA, Reid PC, Stachura MM, Stemmann L, Sugisaki H (2015) Synchronous marine pelagic regime shifts in the Northern Hemisphere. Philos Trans R Soc B 370:20130272. https://doi.org/10.1038/s4155 8-019-0420-1

Beaugrand G, Conversi A, Atkinson A, Cloern J, Chiba S, Fonda-Umani S, Kirby RR, Greene CH, Goberville E, Otto SA (2019) Prediction of unprecedented biological shifts in the global ocean. Nat Clim Change 9:237. https://doi.org/10.1038/s41558-019-0420-1 
Bellwood DR, Hughes TP, Folke C, Nyström M (2004) Confronting the coral reef crisis. Nature 429:827. https://doi.org/10.1038/nature02691

Bellwood DR, Pratchett MS, Morrison TH, Gurney GG, Hughes TP, Álvarez-Romero JG, Day JC, Grantham R, Grech A, Hoey AS (2019) Coral reef conservation in the Anthropocene: confronting spatial mismatches and prioritizing functions. Biol Cons 236:604-615. https://doi.org/10.1016/j.bioco n.2019.05.056

Benshila R et al. (2020) A deep learning approach for estimation of the nearshore bathymetry. In: Malvárez G, Navas, F. (eds) Proceedings from the international coastal symposium (ICS) 2020 (Seville, Espagne). J Coast Res, 11-15

Benveniste J, Mandea M, Melet A, Ferrier P (in review) Earth observations for coastal hazards monitoring and international services. Surv Geophys

Benveniste J, Cazenave A, Vignudelli S, Fenoglio-Marc L, Shah R, Almar R, Andersen O, Birol F, Bonnefond P, Bouffard J, Calafat F, Cardellach E, Cipollini P, Le Cozannet G, Dufau C, Fernandes MJ, Frappart F, Garrison J, Gommenginger C, Han G, Høyer JL, Kourafalou V, Leuliette E, Li Z, Loisel H, Madsen KS, Marcos M, Melet A, Meyssignac B, Pascual A, Passaro M, Ribó S, Scharroo R, Song YT, Speich S, Wilkin J, Woodworth P, Wöppelmann G (2019) Requirements for a coastal hazards observing system. Front Mar Sci 6:348. https://doi.org/10.3389/fmars.2019.00348

Berardino P, Fornaro G, Lanari R, Sansosti E (2002) A new algorithm for surface deformation monitoring based on small baseline differential SAR interferograms. IEEE Trans Geosci Remote Sens 40(11):2375-2383. https://doi.org/10.1109/TGRS.2002.803792

Bergmann M, Durand F, Krien Y, Jamal Uddin Khan M, Ishaque M, Testut L, Calmant S, Maisongrande P, Saiful Islam AKM, Papa F, Ouillon S (2018) Topography of the intertidal zone along the shoreline of Chittagong (Bangladesh) using PROBA-V imagery. Int J Remote Sens. https://doi. org/10.1080/01431161.2018.1504341

Bergsma E, Almar R (2020) Coastal coverage of ESA's Sentinel 2 mission. Adv Space Res. https://doi. org/10.1016/j.asr.2020.03.001 (in press)

Bergsma EWJ, Almar R, Maisongrande P (2019) Radon-augmented Sentinelii satellite imagery to derive wave-patterns and regional bathymetry. Remote Sens 11(16):1918. https://doi.org/10.3390/rs111 61918

Biggs R, Blenckner T, Folke C, Gordon L, Norström A, Nyström M, Peterson G (2012) Regime shifts. In: Hastings A, Gross L (eds) Encyclopedia of theoretical ecology. University of California Press, Berkeley

Bindoff N et al (2019) Changing ocean, marine ecosystems, and dependent communities. In: IPCC special report on the ocean and cryosphere in a changing climate

Bingham RJ, Hughes CW (2012) Local diagnostics to estimate density-induced sea level variations over topography and along coastlines. J Geophys Res 117(C1):C01013

Bird ECF (1987) The modern prevalence of beach erosion. Mar Pollut Bull 18(4):151-157. https://doi. org/10.1016/0025-326X(87)90238-4

Birol F, Fuller N, Lyard F, Cancet M, Niño F, Delebecque C, Fleury S, Toublanc F, Melet A, Saraceno M, Leger F (2016) Coastal applications from nadir altimetry: example of the X-TRACK regional products. Adv Space Res. https://doi.org/10.1016/j.asr.2016.11.005

Blondeau-Patissier D, Gower JFR, Dekker AG, Phinn SR, Brando VE (2014) A review of ocean color remote sensing methods and statistical techniques for the detection, mapping and analysis of phytoplankton blooms in coastal and open oceans. Prog Oceanogr 123:124-144

Boak EH, Turner IL (2005) Shoreline definition and detection: a review. J Coast Res 21:688-703. https ://doi.org/10.2112/03-0071.1

Bonjean F, Lagerloef GS (2002) Diagnostic model and analysis of the surface currents in the tropical Pacific Ocean. J Phys Oceanogr 32:2938-2954

Breivik $\varnothing$, Allen A (2008) An operational search and rescue model for the Norwegian Sea and the North Sea. J Mar Syst 69(1-2):99-113. https://doi.org/10.1016/j.jmarsys.2007.02.010

Breivik Ø, Allen AA, Maisondieu C, Olagnon M (2013) Advances in search and rescue at sea. Ocean Dyn 63:83-88. https://doi.org/10.1007/s10236-012-0581-1

Burke L, Kura Y, Kasem K, Revenga C, Spalding M, McAllister D (2001) Coastal ecosystems. World Resources Institute, Washington

Caballero I, Stumpf RP (2019) Retrieval of nearshore bathymetry from Sentinel-2A and 2B satellites in South Florida coastal waters. Estuar Coast Shelf Sci 226:106277. https://doi.org/10.1016/j. ecss.2019.106277

Calafat FM, Chambers DP, Tsimplis MN (2012) Mechanisms of decadal sea level variability in the eastern North Atlantic and the Mediterranean Sea. J Geophys Res 117:C09022 
Cazenave A, Le Cozannet G, Benveniste J, Woodworth PL, Champollion N (2017) Monitoring coastal zone changes from space. Eos. https://doi.org/10.1029/2017EO085581

Cazenave A, Palanisamy H, Ablain M (2018) Contemporary sea level changes from satellite altimetry: what have we learned? What are the new challenges? Adv Space Res 62:1639-1653

Chaussard E, Amelung F, Abidin H, Hong S-H (2013) Sinking cities in Indonesia: ALOS PALSAR detects rapid subsidence due to groundwater and gas extraction. Remote Sens Environ 128:150161. https://doi.org/10.1016/j.rse.2012.10.015

Chawla I, Karthikeyan L, Mishra AK (2020) A review of remote sensing applications for water security: quantity, quality and extremes. J Hydrol 585:124826

Chelton DB, Schlax MG, Freilich MH, Milliff RF (2004) Satellite measurements reveal persistent smallscale features in ocean winds. Science 303:978-983. https://doi.org/10.1126/science.1091901

Choi C, Kim DJ (2018) Optimum baseline of a single-pass In-SAR system to generate the best DEM in tidal flats. IEEE J Sel Top Appl Earth Obs Remote Sens 11(3):919-929. https://doi.org/10.1109/JSTAR S.2018.2795107

Choi J-K, Park Y-J, Lee BR, Eom J, Moon J-E, Ryu J-H (2014) Application of the Geostationary Ocean Color Imager (GOCI) to mapping the temporal dynamics of coastal water turbidity. Remote Sens Environ 146:24-35. https://doi.org/10.1016/j.rse.2013.05.032

Cian F, Delgado Blasco JM, Carrera L (2019) Sentinel-1 for monitoring land subsidence of coastal cities in Africa using PSInSAR: a methodology based on the integration of SNAP and StaMPS. Geosciences 9:124. https://doi.org/10.3390/geosciences9030124

Cianflone G, Tolomei C, Brunori CA, Dominici R (2015) InSAR time series analysis of natural and anthropogenic coastal plain subsidence: the case of Sibari (Southern Italy). Remote Sens 7:16004-16023. https://doi.org/10.3390/rs71215812

Cicin-Sain B, Bernal P, Vandeweerd V, Belfiore S, Goldstein K (2002) A guide to oceans, coasts, and islands at the world summit on sustainable development. Center for the Study of Marine Policy, Newark, Delaware, August 2002. http://hdl.handle.net/1834/301. Accessed May 2019

Cipollini P, Calafat FM, Jevrejeva S, Melet A, Prandi P (2017) Monitoring sea level in the coastal zone with satellite altimetry and tide gauges. Surv Geophys 38:33-57. https://doi.org/10.1007/s1071 2-016-9392-0

Collin A, Hench JL, Pastol Y, Planes S, Thiault T, Schmitt RJ, Holbrook SJ, Davies N, Troyer M (2018) High resolution topobathymetry using a Pleiades-1 triplet: moorea island in 3D. Remote Sens Environ 208:109-119. https://doi.org/10.1016/j.rse.2018.02.015

Commission European (2008) Directive 2008/56/EC of the European Parliament and of the Council of 17 June 2008, establishing a framework for community action in the field of marine environmental policy (Marine Strategy Framework Directive). Off J Eur Union L 164:19-40

Conversi A, Umani SF, Peluso T, Molinero JC, Santojanni A, Edwards M (2010) The Mediterranean Sea regime shift at the end of the 1980s, and intriguing parallelisms with other European basins. PLoS ONE 5(5):e10633. https://doi.org/10.1371/journal.pone.0010633

Conversi A, Dakos V, Gardmark A, Ling S, Folke C, Mumby PJ, Greene C, Edwards M, Blenckner T, Casini M, Pershing A, Moellmann C (2015) A holistic view of marine regime shifts. Philos Trans R Soc B Biol Sci 370:8. https://doi.org/10.1098/rstb.2013.0279

Corbau C, Simeoni U, Zoccarato C, Mantovani G, Teatini P (2019) Coupling land use evolution and subsidence in the Po Delta, Italy: revising the past occurrence and prospecting the future management challenges. Sci Total Environ 654:1196-1208. https://doi.org/10.1016/j.scitotenv.2018.11.104

Cramer W, Yohe GW, Auffhammer M, Huggel C, Molau U, da Silva Dias MAF, Solow A, Stone DA, Tibig L (2014) Detection and attribution of observed impacts. In: Field CB, Barros VR, Dokken DJ, Mach KJ, Mastrandrea MD, Bilir TE, Chatterjee M, Ebi KL, Estrada YO, Genova RC, Girma B, Kissel ES, Levy AN, MacCracken S, Mastrandrea PR, White LL (eds) Climate change 2014: impacts, adaptation, and vulnerability. Part A: global and sectoral aspects. Contribution of Working Group II to the Fifth Assessment Report of the Intergovernmental Panel on Climate Change. Cambridge University Press, Cambridge, pp 979-1037

Crossland C, Baird D, Ducrotoy J-P, Lindeboom H, Buddemeier R, Dennison W et al (2005) The coastal zone-a domain of global interactions. In: Crossland C, Kremer H, Lindeboom H, Marshall Crossland J, Tissier MA (eds) Coastal fluxes in the Anthropocene. Springer, Berlin, pp 1-37. https://doi. org/10.1007/3-540-27851-6

D’Asaro E, Shcherbina AY, Klymak JM, Molemaker J, Novelli G, Guigand CM et al (2018) Ocean convergence and the dispersion of flotsam. Proc Natl Acad Sci USA 115:201718453. https://doi. org/10.1073/pnas.1718453115 
Da Lio C, Teatini P, Strozzi T, Tosi L (2018) Understanding land subsidence in salt marshes of the Venice Lagoon from SAR Interferometry and ground-based investigations. Remote Sens Environ 205:56-70. https://doi.org/10.1016/j.rse.2017.11.016

Danilo C, Binet R (2013) Bathymetry estimation from wave motion with optical imagery: influence of acquisition parameters. IEEE Trans Geosci Remote Sens. https://doi.org/10.1109/OCEANS-Berge n.2013.6608068

Danilo C, Melgani F (2019) High-coverage satellite-based coastal bathymetry through a fusion of physical and learning methods. Remote Sens 11:376

De Dominicis M, Pinardi N, Zodiatis G, Archetti R (2013) MEDSLIK-II, a Lagrangian marine surface oil spill model for short-term forecasting-part 2: numerical simulations and validations. Geosci Model Dev 6:1871-1888. https://doi.org/10.5194/gmd-6-1871-2013

de Kloe J, Stoffelen A, Verhoef A (2017) Improved use of scatterometer measurements by using stressequivalent reference winds. IEEE J Sel Top Appl Earth Observ Remote Sens 10:2340-2347. https ://doi.org/10.1109/JSTARS.2017.2685242

De Mey-Frémaux P, Ayoub N, Barth A, Brewin R, Charria G, Campuzano F, Ciavatta S, Cirano M, Edwards CA, Federico I, Gao S, Garcia Hermosa I, Garcia Sotillo M, Hewitt H, Hole LR, Holt J, King R, Kourafalou V, Lu Y, Mourre B, Pascual A, Staneva J, Stanev EV, Wang H, Zhu X (2019) Model-observations synergy in the coastal ocean. Front Mar Sci 6:436. https://doi.org/10.3389/ fmars.2019.00436

de Young B, Barange M, Beaugrand G, Harris R, Perry RI, Scheffer M, Werner F (2008) Regime shifts in marine ecosystems: detection, prediction and management. Trends Ecol Evol 23:402-409. https ://doi.org/10.1016/j.tree.2008.03.008

Dinardo S, Fenoglio-Marc L, Buchhaupt C, Becker M, Scharroo R, Fernandes MJ, Benveniste J (2018) Coastal SAR and PLRM altimetry in German Bight and West Baltic Sea. Adv Space Res 62(6):1371-1404. https://doi.org/10.1016/j.asr.2017.12.018

Dixon TH, Amelung F, Ferretti A, Novali F, Rocca F, Dokka R, Sella G, Kim S-W, Wdowinski S, Whitman D (2006) Subsidence and flooding in New Orleans. Nature 441:587-588. https://doi. org/10.1038/441587a

Dodet G, Melet A, Ardhuin F, Bertin X, Idier D, Almar R (2019) The contribution of wind-generated waves to coastal sea-level changes. Surv Geophys 40(6):1563-1601. https://doi.org/10.1007/s1071 2-019-09557-5

Dohan K, Maximenko N (2010) Monitoring ocean currents with satellite sensors. Oceanography 23:94103. https://doi.org/10.5670/oceanog.2010.08

Dorji P, Fearns P (2018) Atmospheric correction of geostationary Himawari-8 satellite data for Total Suspended Sediment mapping: a case study in the Coastal Waters of Western Australia. ISPRS J Photogramm Remote Sens 144:81-93. https://doi.org/10.1016/j.isprsjprs.2018.06.019

Doxaran D, Lamquin N, Park Y-J, Mazeran C, Ryu J-H, Wang M, Poteau A (2014) Retrieval of the seawater reflectance for suspended solids monitoring in the East China Sea using MODIS, MERIS and GOCI satellite data. Remote Sens Environ 146:36-48. https://doi.org/10.1016/j. rse.2013.06.020

Durand F, Piecuch CG, Becker M, Papa F, Raju SV, Khan JU, Ponte RM (2019) Impact of continental freshwater runoff on coastal sea level. Surv Geophys 40:1437. https://doi.org/10.1007/s1071 2-019-09536-w

Duvat VK (2019) A global assessment of atoll island planform changes over the past decades. Wiley Interdiscip Rev Clim Change 10(1):e557. https://doi.org/10.1002/wcc.557

Erban LE, Gorelick SM, Zebker HA (2014) Groundwater extraction, land subsidence, and sea-level rise in the Mekong Delta, Vietnam. Environ Res Lett 9:084010. https://doi.org/10.1088/17489326/9/8/084010

Eriksson BK, van der Heide T, van de Koppel J, Piersma T, van der Veer HW, Olff H (2010) Major changes in the ecology of the Wadden Sea: human impacts, ecosystem engineering and sediment dynamics. Ecosystems 13:752-764. https://doi.org/10.1007/s10021-010-9352-3

Ettritch G, Hardy A, Bojang L, Cross D, Bunting P, Brewer P (2018) Enhancing digital elevation models for hydraulic modelling using flood frequency detection. Remote Sens Environ 217:506-522. https ://doi.org/10.1016/j.rse.2018.08.029

Evagorou EG, Mettas C, Agapiou A, Themistocleous K, Hadjimitsis DG (2019) Bathymetric maps from multi-temporal analysis of Sentinel-2 data: the case study of Limassol. Cyprus. Adv. Geosci. 45:397-407

FAO (1998) FAO Technical guidelines for responsible fisheries-fishing operations-1 Suppl. 1-1. In: Vessel monitoring systems. Food and Agriculture of the United Nations, M-41, ISBN 92-5104179-2, Rome 
Farcas A, Thompson PM, Merchant ND (2016) Underwater noise modelling for environmental impact assessment. Environ Impact Assess Rev 57:114-122. https://doi.org/10.1016/j.eiar.2015.11.012

Farr TG et al (2007) The Shuttle radar topography mission. Rev Geophys 45:RG2004. https://doi. org/10.1029/2005RG000183

Ferretti A, Prati C, Rocca F (2001) Permanent scatterers in SAR interferometry. IEEE Trans Geosci Remote Sens 39(1):8-20. https://doi.org/10.1109/36.898661

Ferretti A, Fumagalli A, Novali F, Prati C, Rocca F, Rucci A (2011) A new algorithm for processing interferometric data-stacks: Squee-SAR ${ }^{\mathrm{TM}}$. IEEE Trans Geoscid Remote Sens 49(9):3460-3470

Fingas M, Brown CE (2018) A review of oil spill remote sensing. Sensors 18:91. https://doi.org/10.3390/ s18010091

Gabriel AK, Goldstein RM, Zebker HA (1989) Mapping small elevation changes over large areas: differential radar interferometry. J Geophys Res 94(B7):9183-9191. https://doi.org/10.1029/JB094iB07p 09183

Gao J (2009) Bathymetric mapping by means of remote sensing: methods, accuracy and limitations. Prog Phys Geogr 33:103-116. https://doi.org/10.1177/0309133309105657

Garcin M, Vendé-Leclerc M, Maurizot P, Le Cozannet G, Robineau B, Nicolae-Lerma A (2016) Lagoon islets as indicators of recent environmental changes in the South Pacific-The New Caledonian example. Cont Shelf Res 122:120-140. https://doi.org/10.1016/j.csr.2016.03.025

Gattuso JP, Magnan A, Billé R, Cheung WW, Howes EL, Joos F, Allemand D, Bopp L, Cooley SR, Eakin CM, Hoegh-Guldberg O (2015) Contrasting futures for ocean and society from different anthropogenic $\mathrm{CO}_{2}$ emissions scenarios. Science 349(6243):4722. https://doi.org/10.1126/science.aac4722

Gebremichael E, Sultan M, Becker R, El Bastawesy M, Cherif O, Emil M (2018) Assessing land deformation and sea encroachment in the Nile Delta: a radar interferometric and inundation modeling approach. J Geophys Res Solid Earth 123:3208-3224. https://doi.org/10.1002/2017JB015084

Goldstein EB, Coco G, Plant NG (2019) A review of machine learning applications to coastal sediment transport and morphodynamics. Earth Sci Rev 194:97-108. https://doi.org/10.1016/j.earsc irev.2019.04

Gommenginger C (2019) SEASTAR: a mission to study ocean submesoscale dynamics and small-scale atmosphere-ocean processes in coastal, shelf and polar seas. Front Mar Sci. https://doi.org/10.13140/ RG.2.2.20415

Greidanus H, Alvarez M, Santamaria C, Thoorens FX, Kourti N, Argentieri P (2017) The SUMO ship detector algorithm for satellite radar images. Remote Sens 9:246. https://doi.org/10.3390/rs9030246

Guerrini F, Mari L, Casagrandi R (2019) Modeling plastics exposure for the marine biota: risk maps for fin whales in the Pelagos Sanctuary (North-Western Mediterranean). Frontiers in Marine Science. https:// doi.org/10.3389/fmars.2019.00299

Hallegatte S, Green C, Nicholls RJ, Corfee-Morlot J (2013) Future flood losses in major coastal cities. Nat Clim Change 3(9):802. https://doi.org/10.1038/nclimate1979

Ham Y-G, Kim J-H, Luo J-J (2019) Deep learning for multi-year ENSO forecasts. Nature 573:568-572

Hamon M, Greiner E, Remy E, Le Traon PY (2019) Impact of multiple altimeter data and mean dynamic topography in a global analysis and forecasting system. J Atmos Ocean Technol. https://doi. org/10.1175/JTECH-D-18-0236.1

Hasselmann K, Chapron B, Aouf L, Ardhuin F, Collard F, Engen G et al (2012) The ERS SAR wave mode: a breakthrough in global ocean wave observations. In: ERS Missions: 20 years of observing earth. European Space Agency, Noordwijk, pp 165-198

Hawkins AD, Popper AN (2017) A sound approach to assessing the impact of underwater noise on marine fishes and invertebrates. ICES J Mar Sci 74(3):635-651. https://doi.org/10.1093/icesjms/fsw205

Heron SF, Maynard JA, van Hooidonk R, Eakin CM (2016) Warming trends and bleaching stress of the world's coral reefs 1985-2012. Sci Rep 6:38402. https://doi.org/10.1038/srep38402

Hersbach H, Bell B, Berrisford P, Horányi A, Muñoz Sabater J, Nicolas J, Radu R, Schepers D, Simmons A, Soci C, Dee D (2019) Global reanalysis: Goodbye ERA-interim, hello ERA5. ECMWF Newsletter No. 159:17-24. http://dx.doi.org/10.21957/vf291hehd7

Heygster G, Dannenberg J, Notholt J (2010) Topographic mapping of the german tidal flats analyzing SAR images with the waterline method. IEEE Trans Geosci Remote Sens 48(3):1019-1030

Higgins SA, Overeem I, Steckler MS, Syvitski JPM, Seeber L, Akhter SH (2014) InSAR measurements of compaction and subsidence in the Ganges-Brahmaputra Delta, Bangladesh. J Geophys Res Earth Surf 119:1768-1781. https://doi.org/10.1002/2014JF003117

Hildebrand JA (2005) Impacts of anthropogenic sound. In: Reynolds JE III, Perrin WF, Reeves RR, Montgomery S, Ragen TJ (eds) Marine mammal research: conservation beyond crisis. The John Hopkins University Press, Baltimore, pp 101-124 
Hinkel J, Lincke D, Vafeidis AT, Perrette M, Nicholls RJ, Tol RS, Marzeion B, Fettweis X, Ionescu C, Levermann A (2014) Coastal flood damage and adaptation costs under 21st century sea-level rise. Proc Natl Acad Sci 111(9):3292-3297. https://doi.org/10.1073/pnas.1222469111

Hoegh-Guldberg O, Cai R, Poloczanska ES, Brewer PG, Sundby S, Hilmi K, Fabry VJ, Jung S (2014) The Ocean. In: Barros VR, Field CB, Dokken DJ, Mastrandrea MD, Mach KJ, Bilir TE, Chatterjee M, Ebi KL, Estrada YO, Genova RC, Girma B, Kissel ES, Levy AN, MacCracken S, Mastrandrea PR, White LL (eds) Climate change 2014: impacts, adaptation, and vulnerability. Part B: regional aspects. Contribution of Working Group II to the Fifth Assessment Report of the Intergovernmental Panel on Climate Change. Cambridge University Press, Cambridge, pp 1655-1731

Holling CS (1973) Resilience and stability of ecological systems. Annu Rev Ecol Syst 4:1-23. https:// doi.org/10.1146/annurev.es.04.110173.000245

Holman RA, Lalejini D, Holland KT (2016) A parametric model for barred equilibrium beach profiles: two-dimensional implementation. Coast Eng 117:166-175. https://doi.org/10.1016/j.coastaleng .2016.07.010

Huang C, Yang H, Zhu AX, Zhang M, Lü H, Huang T et al (2015) Evaluation of the Geostationary Ocean Color Imager (GOCI) to monitor the dynamic characteristics of suspension sediment in Taihu Lake. Int J Remote Sens 36:3859-3874. https://doi.org/10.1080/01431161.2015.1070323

Hughes TP (1994) Catastrophes, phase shifts, and large-scale degradation of a Caribbean coral reef. Science 265:1547-1551

Hughes TP, Carpenter S, Rockström J, Scheffer M, Walker B (2013) Multiscale regime shifts and planetary boundaries. Trends Ecol Evol 28:389-395. https://doi.org/10.1016/j.tree.2013.05.019

Hughes TP, Kerry JT, Álvarez-Noriega M, Álvarez-Romero JG, Anderson KD, Baird AH, Babcock RC, Beger M, Bellwood DR, Berkelmans R, Bridge TC, Butler IR, Byrne M, Cantin NE, Comeau S, Connolly SR, Cumming GS, Dalton SJ, Diaz-Pulido G, Eakin CM, Figueira WF, Gilmour JP, Harrison HB, Heron SF, Hoey AS, Hobbs J-PA, Hoogenboom MO, Kennedy EV, Kuo C-y, Lough JM, Lowe RJ, Liu G, McCulloch MT, Malcolm HA, McWilliam MJ, Pandolfi JM, Pears RJ, Pratchett MS, Schoepf V, Simpson T, Skirving WJ, Sommer B, Torda G, Wachenfeld DR, Willis BL, Wilson SK (2017) Global warming and recurrent mass bleaching of corals. Nature 543:373-377. https ://doi.org/10.1038/nature21707

Hughes CW, Fukumori I, Griffies SM, Huthnance JM, Minobe S, Spence P, Thompson KR, Wise A (2019) Sea level and the role of coastal trapped waves in mediating the influence of the open ocean on the coast. Surv Geophys 40:1467-1492

Hugo G (2011) Future demographic change and its interactions with migration and climate change. Glob Environ Change 21S:S21-S33. https://doi.org/10.1016/j.gloenvcha.2011.09.008

Idier D, Bertin X, Thompson P, Pickering MD (2019) Interactions between mean sea level, tide, surge, waves and flooding: mechanisms and contributions to sea level variations at the coast. Surv Geophys. https://doi.org/10.1007/s10712-019-09549-5

IGOS (2006) A coastal theme for the IGOS partnership-for the monitoring of our environment from space and from earth. Paris, UNESCO 2006. 60 pp. (IOC Information document No. 1220)

IMO (2000) SOLAS Convention 1974, Chapter V, Regulation 19 (Amended 6 Dec 2000)

IMO (2006) SOLAS Convention 1974, Chapter V, Regulation 19-1 (Adopted 19 May 2006)

Ingebritsen SE, Galloway DL (2014) Coastal subsidence and relative sea level rise. Environ Res Lett 9:091002. https://doi.org/10.1016/j.gloenvcha.2011.09.008

IOCCG (2000) Remote sensing of ocean colour in coastal, and other optically-complex, waters. In: Sathyendranath S (ed) Reports of the International Ocean-Colour Coordinating Group, No. 3, IOCCG, Dartmouth, Canada

IOCCG (2008) Why ocean colour? The societal benefits of ocean-colour technology. In: Platt T, Hoepffner N, Stuart V, Brown C (eds) Reports of the International Ocean-Colour Coordinating Group, No. 7, IOCCG, Dartmouth, Canada

IOCCG (2018) Earth observations in support of global water quality monitoring. In: Greb S, Dekker A, Binding C (eds) IOCCG Report Series, No. 17, International Ocean Colour Coordinating Group, Dartmouth, Canada

IPBES (2019) Global assessment report on biodiversity and ecosystem services of the Intergovernmental Science-Policy Platform on Biodiversity and Ecosystem Services. In: Brondizio ES, Settele J, Díaz S, Ngo HT (eds) IPBES secretariat, Bonn, Germany

Jambeck JR, Geyer R, Wilcox C, Siegler TR, Perryman M, Andrady A, Narayan R, Law KL (2015) Plastic waste inputs from land into the ocean. Science 347(6223):768-771

Jawak SD, Vadlamani SS, Luis AJ (2015) A synoptic review on deriving bathymetry information using remote sensing technologies: models, methods and comparisons. Adv Remote Sens 4:147-162. https://doi.org/10.4236/ars.2015.42013 
Kamenos NA, Hennige SJ (2018) Reconstructing four centuries of temperature-induced coral bleaching on the Great Barrier Reef. Front Mar Sci 5:283. https://doi.org/10.3389/fmars.2018.00283

Kanjir U, Greidanus H, Oštir C (2018) Vessel detection and classification from spaceborne optical images: a literature survey. Remote Sens Environ 207:1-26

Karunarathna H, Horrillo-Caraballo J, Kuriyama Y, Mase H, Ranasinghe R, Reeve DE (2016) Linkages between sediment composition, wave climate and beach profile variability at multiple timescales. Mar Geol 381:194-208

Khan MJU, Ansary MN, Durand F, Testut L, Ishaque M, Calmant S, Krien Y, Islam AS, Papa F (2019) High-resolution intertidal topography from Sentinel-2 multi-spectral imagery: synergy between remote sensing and numerical modeling. Remote Sens 11:2888

Kharif C, Pelinovsky E (2003) Physical mechanisms of the rogue wave phenomenon. Eur J Mech B/Fluids 22:603-634

Kroodsma DA, Mayorga J, Hochberg T, Miller NA, Boerder K, Ferretti F, Wilson A, Bergman B, White TD, Block BA, Woods P, Sullivan B, Costello C, Worm B (2018) Tracking the global footprint of fisheries. Science 359:904-908

Kudryavtsev V, Yurovskaya M, Chapron B, Collard F, Donlon C (2017) Sun glitter imagery of ocean surface waves. Part 1: directional spectrum retrieval and validation. J Geophys Res (Oceans) 122(2):1369-1383

Kulp SA, Strauss BH (2018) CoastalDEM: a global coastal digital elevation model improved from SRTM using a neural network. Remote Sens Environ 206:231-239. https://doi.org/10.1016/j.rse.2017.12.026

Kwiatkowska EJ, Ruddick K, Ramon D, Vanhellemont Q, Brockmann C, Lebreton C, Bonekamp HG (2016) Ocean colour opportunities from Meteosat Second and Third Generation geostationary platforms. Ocean Sci 12:703-713. https://doi.org/10.5194/os-12-703-2016

Lauerburg RAM, Diekmann R, Blanz B, Gee K, Held H, Kannen A, Möllmann C, Probst WN, Rambo H, Cormier R, Stelzenmüller V (2020) Socio-ecological vulnerability to tipping points: a review of empirical approaches and their use for marine management. Sci Total Environ 705:135838

Le Cozannet G, Garcin M, Yates M, Idier D, Meyssignac B (2014) Approaches to evaluate the recent impacts of sea-level rise on shoreline changes. Earth Sci Rev 138:47-60. https://doi.org/10.1016/j. earscirev.2014.08.005

Le Cozannet G, Kervyn M, Russo S, Ifejika-Speranza C, Ferrier P, Foumelis M, Modaressi H (2020) Spacebased earth observations for disaster risk management. Surv Geophys. https://doi.org/10.1007/s1071 2-020-09586-5

Le Roy S, Pedreros R, André C, Paris F, Lecacheux S, Marche F, Vinchon C (2015) Coastal flooding of urban areas by overtopping: dynamic modelling application to the Johanna storm (2008) in Gâvres (France). Nat Hazards Earth Syst Sci 15(11):2497-2510. https://doi.org/10.5194/nhess-15-2497-2015

Le Traon PY (2018) Satellites and operational oceanography. In: Chassignet E, Pascual A, Tintoré J, Verron J (eds) New frontiers in operational oceanography. GODAE OceanView, Met Office, pp 161-190. https://doi.org/10.17125/gov2018.ch07

Le Traon PY, Antoine D, Bentamy A, Bonekamp H, Breivik LA, Chapron B et al (2015) Use of satellite observations for operational oceanography: recent achievements and future prospects. J Oper Oceanogr 8:s12-s27

Le Traon PY, Dibarboure G, Jacobs G, Martin M, Remy E, Schiller A (2017) Use of satellite altimetry for operational oceanography. In: Stammer D, Cazenave A (eds) Satellite altimetry over oceans and land surfaces. CRC Press, Boca Raton

Le Traon PY et al (2019) From observation to information and users: the copernicus marine service perspective. Front Mar Sci 6:234. https://doi.org/10.3389/fmars.2019.00234

Lee SK, Ryu JH (2017) High-accuracy tidal flat digital elevation model construction using TanDEMX science phase data. IEEE J Sel Top Appl Earth Obs Remote Sens 10(6):2713-2724. https://doi. org/10.1109/JSTARS.2017.2656629

Lee ZP, Carder KL, Mobley CD, Steward RG, Patch JS (1998) Hyperspectral remote sensing for shallow waters: deriving bottom depths and water properties by optimization. Appl Opt 38(18):3831-3843. https://doi.org/10.1364/AO.38.003831

Lenton TM, Rockström J, Gaffney O, Rahmstorf S, Richardson K, Steffen W, Schellnhuber HJ (2019) Climate tipping points- too risky to bet against. Nature 575:592-595. https://doi.org/10.1038/d4158 6-019-03595-0

Li Z, Heygster G, Notholt J (2014) Intertidal topographic maps and morphological changes in the German Wadden Sea between 1996-1999 and 2006-2009 from the waterline method and SAR images. IEEE J Sel Top Appl Earth Obs Remote Sens 7(8):3210-3224

Liubartseva S, Coppini G, Lecci R, Clementi E (2018) Tracking plastics in the Mediterranean: 2D Lagrangian model. Mar Pollut Bull 129:151-162 
Loisel H, Mangin A, Vantrepotte V, Dessailly D, Dinh DN, Garnesson P, Ouillon S, Lefebvre JP, Mériaux X, Phan TM (2014) Variability of suspended particulate matter concentration in coastal waters under the Mekong's influence from ocean color (MERIS) remote sensing over the last decade. Remote Sens Environ 150:218-230. https://doi.org/10.1016/j.rse.2014.05.006

Loisel H, Vantrepotte V, Ouillon S, Ngoc DD, Herrmann M, Tran V et al (2017) Assessment and analysis of the chlorophyll-a concentration variability over the Vietnamese coastal waters from the MERIS ocean color sensor (2002-2012). Remote Sens Environ 190:217-232. https://doi.org/10.1016/j. rse.2016.12.016

Longuevergne et al. (in review)

Lotze HK, Reise K, Worm B, van Beusekom J, Busch M, Ehlers A, Heinrich D, Hoffmann RC, Holm P, Jensen C, Knottnerus OS, Langhanki N, Prummel W, Vollmer M, Wolff WJ (2005) Human transformations of the Wadden Sea ecosystem through time: a synthesis. Helgol Mar Res 59:84-95. https:// doi.org/10.1007/s10152-004-0209-Z

Luijendijk A, Hagenaars G, Ranasinghe R, Baart F, Donchyts G, Aarninkhof S (2018) The state of the world's beaches. Sci Rep 8(1):6641. https://doi.org/10.1038/s41598-018-24630-6

Lyzenga DR (1978) Passive remote sensing techniques for mapping water depth and bottom features. Appl Opt 17(3):379-383. https://doi.org/10.1364/AO.17.000379

Maes C, Grima N, Blanke B, Martinez E, Paviet-Salomon T, Huck T (2018) A surface "superconvergence" pathway connecting the South Indian Ocean to the subtropical South Pacific gyre. Geophys Res Lett 45:1915-1922. https://doi.org/10.1002/2017GL076366

Marcos M, Wöppelmann G, Matthews A, Ponte RM, Birol F, Ardhuin F, Coco G, Santamaria-Gomez A, Ballu V, Testut L, Chambers D, Stopa JE (2019) Coastal sea level and related fields from existing observing systems. Surv Geophys 40(6):1293-1317

Marti F, Cazenave A, Birol F, Passaro M, Leger F, Nino F, Almar R, Benveniste J, Legeais JF (2019) Altimetry-based sea level trends along the coasts of western Africa. Adv Space Res. https://doi. org/10.1016/j.asr.2019.05.033 (in press)

Martínez ML, Intralawan A, Vázquez G, Pérez-Maqueo O, Sutton P, Landgrave R (2007) The coasts of our world: ecological, economic and social importance. Ecol Econ 63:254-272. https://doi.org/10.1016/j. ecolecon.2006.10.022

Mason DC, Davenport IJ, Robinson GJ, Flather RA, Mccartney BS (1995) Construction of an inter-tidal digital elevation model by the "water-line" method. Geophys Res Lett 22(23):3187-3190

Matthews MW (2011) A current review of empirical procedures of remote sensing in inland and near-coastal transitional waters. Int J Remote Sens 32:6855-6899. https://doi.org/10.1080/01431161.2010.512947

Matz MV, Treml EA, Aglyamova GV, Bay LK (2018) Potential and limits for rapid genetic adaptation to warming in a Great Barrier Reef coral. PLoS Genet 14:e1007220. https://doi.org/10.1371/journ al.pgen.1007220

Mayer L, Jakobsson M, Allen G, Dorschel B, Falconer R, Ferrini V et al (2018) The Nippon foundationGEBCO seabed 2030 project: the quest to see the world's oceans completely mapped by 2030 . Geosciences 8:63. https://doi.org/10.3390/geosciences 8020063

McCarthy BL (2010) Coastal bathymetry using satellite observation in support of intelligence preparation of the environment, Calhoun thesis: The NPS Institutional Archive DSpace Repository

McGranahan G, Balk D, Anderson B (2007) The rising tide: assessing the risks of climate change and human settlements in low elevation coastal zones. Environ Urban 19:17-37. https://doi. org/10.1177/0956247807076960

Medina-Lopez E, Ureña-Fuentes L (2019) High-resolution sea surface temperature and salinity in coastal areas worldwide from raw satellite data. Remote Sens 11(19):2191. https://doi.org/10.3390/rs111 92191

Melet A, Meyssignac B, Almar R, Le Cozannet G (2018) Under-estimated wave contribution to coastal sealevel rise. Nat Clim Change 8(3):234. https://doi.org/10.1038/s41558-018-0088-y

Menendez M, Woodworth P (2010) Changes in extreme high water levels based on a quasi-global tidegauge data set. J Geophys Res 115:C10011. https://doi.org/10.1029/2009JC005997

Mentaschi L, Vousdoukas MI, Pekel JF, Voukouvalas E, Feyen L (2018) Global long-term observations of coastal erosion and accretion. Sci Rep 8(1):12876. https://doi.org/10.1038/s41598-018-30904-w

Merchant ND (2019) Underwater noise abatement: economic factors and policy options. Environ Sci Policy 92:116-123. https://doi.org/10.1016/j.envsci.2018.11.014

Merchant ND, Brookes KL, Faulkner RC, Bicknell AWJ, Godley BJ, Witt MJ (2016) Underwater noise levels in UK waters. Sci Rep 6:36942. https://doi.org/10.1038/srep36942

Moellmann C, Conversi A, Edwards M (2011) Comparative analysis of European wide marine ecosystem shifts: a large-scale approach for developing the basis for ecosystem-based management. Biol Lett 7:484-486. https://doi.org/10.1098/rsbl.2010.1213 
Möllmann C, Folke C, Edwards M, Conversi A (2015) Marine regime shifts around the globe: theory, drivers and impacts. Philos Trans R Soc Lond B Biol Sci 370(1659):20130260. https://doi.org/10.1098/ rstb.2013.0260

Monteys X, Harris P, Caloca S, Cahalane C (2015) Spatial prediction of coastal bathymetry based on multispectral satellite imagery and multibeam data. Remote Sens 7(10):13782-13806. https://doi. org/10.3390/rs71013782

Mouw CB, Greb S, Aurin D, DiGiacomo PM, Lee Z, Twardowski M, Binding C, Hu C, Ma R, Moore T, Moses W, Craig SE (2015) Aquatic color radiometry remote sensing of coastal and inland waters: challenges and recommendations for future satellite missions. Remote Sens Environ 160:15-30. https ://doi.org/10.1016/j.rse.2015.02.001

Nayak PK, Armitage D (2018) Social-ecological regime shifts (SERS) in coastal systems. Ocean Coast Manag 161:84-95. https://doi.org/10.1016/j.ocecoaman.2018.04.020

NEREUS/ESA/EC (2018) The ever growing use of copernicus across Europe's regions. https://www.coper nicus.eu/sites/default/files/2018-10/copernicus4regions.pdf. Accessed Sept 2019

Neukermans G, Ruddick K, Bernard E, Ramon D, Nechad B, Deschamps P-Y (2009) Mapping total suspended matter from geostationary satellites: a feasibility study with SEVIRI in the Southern North Sea. Opt Express 17:14029-14052. https://doi.org/10.1364/OE.17.014029

Neukermans G, Ruddick KG, Greenwood N (2012) Diurnal variability of turbidity and light attenuation in the southern North Sea from the SEVIRI geostationary sensor. Remote Sens Environ 124:564-580. https://doi.org/10.1016/j.rse.2012.06.003

Neumann B, Vafeidis AT, Zimmermann J, Nicholls RJ (2015) Future coastal population growth and exposure to sea-level rise and coastal flooding - a global assessment. PLoS ONE 10(3):e0118571. https:// doi.org/10.1371/journal.pone.0118571

Ng AH-M, Ge L, Li X, Abidin HZ, Andreas H, Zhang K (2012) Mapping land subsidence in Jakarta, Indonesia using persistent scatterer interferometry (PSI) technique with ALOS PALSAR. Int J Appl Earth Obs Geoinf 18:232-242. https://doi.org/10.1016/j.jag.2012.01.018

Ngoc DD, Loisel H, Jamet C, Vantrepotte V, Duforêt-Gaurier L, Minh CD, Mangin A (2019) Coastal and inland water pixels extraction algorithm (WiPE) from spectral shape analysis and HSV transformation applied to Landsat 8 OLI and Sentinel-2 MSI. Remote Sens Environ 223:208-228

Nim CJ, Skirving WJ, Eakin CM (2010) Satellite monitoring of reef vulnerability in a changing climate. NOAA Technical Report CRCP 1. NOAA Coral Reef Conservation Program. Silver Spring, MD. http://doi.org/10.1126/science.aaf9933

Normille N (2016) Survey confirms worst-ever coral bleaching at Great Barrier Reef. Science. https://doi. org/10.1126/science.aaf9933

O'Carroll AG, Armstrong EM, Beggs HM, Bouali M, Casey KS, Corlett GK, Dash P, Donlon CJ, Gentemann CL, Høyer JL, Ignatov A, Kabobah K, Kachi M, Kurihara Y, Karagali I, Maturi E, Merchant CJ, Marullo S, Minnett PJ, Pennybacker M, Ramakrishnan B, Ramsankaran R, Santoleri R, Sunder S, Saux Picart S, Vázquez-Cuervo J, Wimmer W (2019) Observational needs of sea surface temperature. Front Mar Sci 6:420. https://doi.org/10.3389/fmars.2019.00420

Odermatt D, Gitelson A, Brando VE, Schaepman M (2012) Review of constituent retrieval in optically deep and complex waters from satellite imagery. Remote Sens Environ 118:116-126. https://doi. org/10.1016/j.rse.2011.11.013

Ody A, Doxaran D, Vanhellemont Q, Nechad B, Novoa S, Many G, Bourrin F, Verney R, Pairaud I, Gentili B (2016) Potential of high spatial and temporal ocean color satellite data to study the dynamics of suspended particles in a micro-tidal river plume. Remote Sens 8(3):245

OECD (2016) The Ocean Economy in 2030. OECD Publishing, Paris. https://doi.org/10.1787/9789264251 724-en

Oliver EC, Burrows MT, Donat MG, Sen Gupta A, Alexander LV, Perkins-Kirkpatrick S, Benthuysen JA, Hobday AJ, Holbrook NJ, Moore PJ, Thomsen MS, Wernberg T, Smale DA (2019) Projected marine heatwaves in the 21st century and potential for ecological impact. Front Mar Sci 6:734

Oppenheimer M, Glacovic B, Hinkel J, Van De Wal R, Magnan A, Abd-Elgawad A, Cai R, Cifuentes-Jara M, Deconto R, Ghosh T, Hay J, Isla F, Marzeion B, Meyssignac M, Sebesvari Z (2019) Sea-level rise and Implications for low lying islands, coasts and communities. Special report on the ocean and cryosphere in a changing climate (SROCC). https://report.ipcc.ch/srocc/pdf/SROCC_FinalDraft_Chapt er4.pdf. (in press)

Pahlevan N, Sarkar S, Franz BA, Balasubramanian SV, He J (2017a) Sentinel-2 MultiSpectral Instrument (MSI) data processing for aquatic science applications: demonstrations and validations. Remote Sens Environ 201:47-56. https://doi.org/10.1016/j.rse.2017.08.033 
Pahlevan N, Schott JR, Franz BA, Zibordi G, Markham B, Bailey S, Schaff CB, Ondrusek M, Greb S, Strait CM (2017b) Landsat 8 remote sensing reflectance (Rrs) products: evaluations, intercomparisons and enhancements. Remote Sens Environ 190:289-301. https://doi.org/10.1016/j.rse.2016.12.030

Pahlevan N, Balasubramanian SV, Sarkar S, Franz BA (2018) Toward long-term aquatic science products from heritage Landsat missions. Remote Sens 10:23. https://doi.org/10.3390/rs10091337

Pahlevan N, Chittimalli SK, Balasubramanian SV (2019) Sentinel-2/Landsat-8 product consistency and implications for monitoring aquatic systems. Remote Sens Environ 220:19-29. https://doi. org/10.1016/j.rse.2018.10.027

Passaro M, Cipollini P, Vignudelli S, Quartly G, Snaith H (2014) ALES: a multi-mission subwaveform retracker for coastal and open ocean altimetry. Remote Sens Environ 145:173-189. https://doi. org/10.1016/j.rse.2014.02.008

Passaro M, Fenoglio-Marc L, Cipollini P (2015) Validation of significant wave height from improved satellite altimetry in the German bight. IEEE Trans Geosci Remote Sens 53(4):2146-2156. https:// doi.org/10.1109/TGRS.2014.2356331

Passaro M, Zulfikar Adlan N, Quartly GD (2018) Improving the precision of sea level data from satellite altimetry with high-frequency and regional sea state bias corrections. Remote Sens Environ 218:245-254. https://doi.org/10.1016/j.rse.2018.09.007

Perez D, Islam K, Hill V, Zimmerman R, Schaeffer B, Li J (2018) Deepcoast: quantifying seagrass distribution in coastal water through deep capsule networks. In: Chinese conference on pattern recognition and computer vision (PRCV). Springer, pp 404-416

Pleskachevsky A, Lehner S, Heege T, Mott C (2011) Synergy and fusion of optical and synthetic aperture radar satellite data for underwater topography estimation in coastal areas. Ocean Dyn 61(12):2099-2120. https://doi.org/10.1007/s10236-011-0460-1

Ponte R, Carson M, Cirano M, Domingues C, Jevrejeva S, Marcos M, Mitchum G, van de Wal R, Woodworth P et al (2019) Towards comprehensive observing and modeling systems for monitoring and predicting regional to coastal sea level. Front Mar Sci. https://doi.org/10.3389/fmars.2019.00437

Popper AN, Hastings MC (2009) Effects of pile driving and other anthropogenic sounds on fish: part 1-critical literature review. J Fish Biol 75:455-489. https://doi.org/10.111 1/j.1095-8649.2009.02319.x

Poupardin A, Idier D, De Michele M, Raucoules D (2015) Water depth inversion from a single SPOT-5 dataset. IEEE Trans Geosci Remote Sens 54(4):2329-2342. https://doi.org/10.1109/ TGRS.2015.2499379

Poupardin A, Idier D, de Michele M, Raucoules D (2016) Water depth inversion from a single SPOT-5 dataset. IEEE Trans Geosci Remote Sens. https://doi.org/10.1109/TGRS.2015.2499379

Quilfen Y, Yurovskaya M, Chapron B, Ardhuin F (2018) Storm waves focusing and steepening in the Agulhas current: satellite observations and modeling. Remote Sens Environ 216:561-571

Ranasinghe R (2016) Assessing climate change impacts on open sandy coasts: a review. Earth-Sci Rev 160:320-332. https://doi.org/10.1016/j.earscirev.2016.07.011

Raucoules D, Le Cozannet G, Wöppelmann G, De Michele M, Gravelle M, Daag A, Marcos M (2013) High nonlinear urban ground motion in Manila (Philippines) from 1993 to 2010 observed by DInSAR: implications for sea-level measurement. Remote Sens Environ 139:386-397. https://doi. org/10.1016/j.rse.2013.08.021

Raucoules D, Le Cozannet G, de Michele M, Capo S (2018) Observing water-level variations from space-borne high-resolution Synthetic Aperture Radar (SAR) image correlation. Geocarto Int 33(9):977-987

Reise K, Baptist M, Burbridge P, Dankers N, Fischer L, Flemming B, Oost AP, Smit C (2010) The Wadden Sea-a universally outstanding tidal wetland. The Wadden Sea 2010 Common Wadden Sea Secretariat (CWSS); Trilateral Monitoring and Assessment Group: Wilhelmshaven (Wadden Sea Ecosystem; 29/editors, Harald Marencic and Jaap de Vlas), Book 7

Ribal A, Young IR (2019) 33 years of globally calibrated wave height and wind speed data based on altimeter observations. Sci Data 6:77. https://doi.org/10.1038/s41597-019-0083-9

Rio MH, Santoleri R (2018) Improved global surface currents from the merging of altimetry and sea surface temperature data. Remote Sens Environ 216:770-785. https://doi.org/10.1016/j.rse.2018.06.003

Rio MH, Mulet S, Picot N (2014) Beyond GOCE for the ocean circulation estimate: synergistic use of altimetry, gravimetry, and in situ data provides new insight into geostrophic and Ekman currents. Geophys Res Lett 41:8918-8925. https://doi.org/10.1002/2014GL061773

Roarty H, Cook T, Hazard L, George D, Harlan J, Cosoli S, Wyatt L, Alvarez Fanjul E, Terrill E, Otero M, Largier J, Glenn S, Ebuchi N, Whitehouse B, Bartlett K, Mader J, Rubio A, Corgnati L, Mantovani C, Griffa A, Reyes E, Lorente P, Flores-Vidal X, Saavedra-Matta KJ, Rogowski P, Prukpitikul 
S, Lee S-H, Lai J-W, Guerin C-A, Sanchez J, Hansen B, Grilli S (2019) The global high frequency radar network. Front Mar Sci 6:164. https://doi.org/10.3389/fmars.2019.00164

Roberts J, Best BD, Mannocci L, Fujioka E, Halpin PN, Palka DL, Garrison LP, Mullin KD, Cole TVN, Khan CB, McLellan WA, Pabst DA, Lockhart GG (2016) Habitat-based cetacean density models for the U.S. Atlantic and Gulf of Mexico. Sci Rep 6:22615. https://doi.org/10.1038/srep22615

Rocha JC, Peterson G, Bodin Ö, Levin S (2018) Cascading regime shifts within and across scales. Science $362: 1379$

Rodriguez E (2019) The winds and currents mission concept. Front. Mar. Sci. https://doi.org/10.3389/ fmars.2019.00438

Roussel N, Ramillien G, Frappart F, Darrozes J, Gay A, Biancale R, Striebig N, Hanquiez V, Bertin X, Allain D (2015) Sea level monitoring and sea state estimate using a single geodetic receiver. Remote Sens Environ 171:261-277

Ruddick K, Neukermans G, Vanhellemont Q, Jolivet D (2013) Challenges and opportunities for geostationary ocean colour remote sensing of regional seas: a review of recent results. Remote Sens Environ 146:63-76. https://doi.org/10.1016/j.rse.2013.07.039

Sagawa T, Yamashita Y, Okumura T, Yamanokuchi T (2019) Satellite derived bathymetry using machine learning and multi-temporal satellite images. Remote Sensing 11:1155

Salama MS, Shen F (2010) Simultaneous atmospheric correction and quantification of suspended particulate matters from orbital and geostationary earth observation sensors. Estuar Coast Shelf Sci 86:499511. https://doi.org/10.1016/j.ecss.2009.10.001

Salameh E, Frappart F, Almar R, Baptista P, Heygster G, Lubac B, Raucoules D, Almeida LP, Bergsma EWJ, Capo S, De Michele M, Idier D, Li Z, Marieu V, Poupardin A, Silva PA, Turki I, Laignel B (2019) Monitoring beach topography and nearshore bathymetry using spaceborne remote sensing: a review. Remote Sens 11(18):2212. https://doi.org/10.3390/rs11192212

Santamaria C, Alvarez M, Greidanus H, Syrris V, Soille P, Argentieri P (2017) Mass processing of Sentinel-1 images for maritime surveillance. Remote Sens 9(7):678. https://doi.org/10.3390/rs9070678

Scheffer M (2009) Critical transitions in nature and society. Princeton University Press, Princeton

Scheffer M, Carpenter SR (2003) Catastrophic regime shifts in ecosystems: linking theory to observation. Trends Ecol Evol 18:648-656. https://doi.org/10.1016/j.tree.2003.09.002

Scheffer M, Carpenter S, Foley JA, Folke C, Walker B (2001) Catastrophic shifts in ecosystems. Nature 413:591-596. https://doi.org/10.1038/35098000

Shearman P, Bryan J, Walsh JP (2013) Trends in deltaic change over three decades in the Asia-Pacific region. J Coastal Res 29(5):1169-1183. https://doi.org/10.2112/JCOASTRES-D-12-00120.1

Shirzaei M, Bürgmann R (2018) Global climate change and local land subsidence exacerbate inundation risk to the San Francisco Bay Area. Science Advances 4(3):eaap923. https://doi.org/10.1126/sciad v.aap9234

Shulz K, Hansch R, Sorgel U (2018) Machine learning methods for remote sensing applications: an overview. In: Earth resources and environmental remote sensing/GIS applications IX, vol 10790. International Society for Optics and Photonics, p 1079002

Slabbekoorn H, Bouton N, van Opzeeland I, Coers A, ten Carte C, Popper AN (2010) A noisy spring: the impact of globally rising underwater sound levels on fish. Trends Ecol Evol 25:419-427. https://doi. org/10.1016/j.tree.2010.04.005

Small C, Nicholls RJ (2003) A global analysis of human settlement in coastal zones. J Coast Res 19(3):584599. https://doi.org/10.2307/4299200

Smith WHF, Sandwell DT (1997) Global seafloor topography from satellite altimetry and ship depth soundings. Science 277:1957-1962

Sosik HM (2008) Characterizing seawater constituents from optical properties. In: Babin M, Roesler CS, Cullen JJ (eds) Real-time coastal observing systems for ecosystem dynamics and harmful algal blooms. UNESCO, Paris, pp 281-329. http://hdl.handle.net/11329/305

Sotillo MG, Cerralbo P, Lorente P, Grifoll M, EspinoM Sanchez-Arcilla A, Álvarez- Fanjul E (2019) Coastal ocean forecasting in Spanish ports: the SAMOA operational service. J Oper Oceanogr. https ://doi.org/10.1080/1755876X.2019.1606765

Staneva J, Wahle K, Koch W, Behrens A, Fenoglio-Marc L, Stanev EV (2016) Coastal flooding: impact of waves on storm surge during extremes-a case study for the German Bight. Nat Hazards Earth Syst Sci 16:2373-2389

Steffen W, Rockström J, Richardson K, Lenton TM, Folke C, Liverman D, Summerhayes CP, Barnosky AD, Cornell SE, Crucifix M, Donges JF, Fetzer I, Lade SJ, Scheffer M, Winkelmann R, Schellnhuber HJ (2018) Trajectories of the earth system in the anthropocene. Proc Natl Acad Sci 115:8252 
Strozzi T, Teatini P, Tosi L, Wegmüller U, Werner C (2013) Land subsidence of natural transitional environments by satellite radar interferometry on artificial reflectors. J Geophys Res Earth Surf 118:11771191. https://doi.org/10.1002/jgrf.20082

Sudre J, Maes C, Garçon V (2013) On the global estimates of geostrophic and Ekman surface currents. Limnol Oceanogr Fluids Environ 3:1-20. https://doi.org/10.1215/21573689-2071927

Swingedouw D, Ifejika-Speranza C, Bartsch A, Durand G, Jamet C, Beaugrand G, Conversi A (in review) Early warning from space for a few key tipping points in physical and biological systems, and in societies. Surv Geophys

Tadono T, Nagai H, Ishida H, Oda F, Naito S, Minakawa K, Iwamoto H (2016) Generation of the 30-m mesh global digital surface model by ALOS PRISM. Int Arch Photogramm Remote Sens Spat Inf Sci XLI-B4:157-162. https://doi.org/10.5194/isprsarchives-XLI-B4-157-2016

Tateishi R, Akutsu A (1992) Relative DEM production from SPOT data without GCP. Int J Remote Sens 13(14):2517-2530. https://doi.org/10.1080/01431169208904061

Teatini P, Tosi L, Strozzi T, Carbognin L, Wegmüller U, Rizzetto F (2005) Mapping regional land displacements in the Venice coastland by an integrated monitoring system. Remote Sens Environ 98(4):403413. https://doi.org/10.1016/j.rse.2005.08.002

Toimil A, Camus P, Losada IJ, Le Cozannet G, Nicholls RJ, Idier D, Maspataud A (2020) Climate change driven coastal erosion modelling in temperate sandy beaches: methods and uncertainty treatment. Earth Sci Rev 202:103110. https://doi.org/10.1016/j.earscirev.2020.103110

Tonani M, Balmaseda M, Bertino L, Blockley E, Brassington G, Davidson F et al (2015) Status and future of global and regional ocean prediction systems. J Oper Oceanogr 8:s201-s220. https://doi. org/10.1080/1755876X.2015.1049892

Tosi L, Teatini P, Carbognin L, Brancolini G (2009) Using high resolution data to reveal depth-dependent mechanisms that drive land subsidence: the Venice coast, Italy. Tectonophysics 474:271-284. https:// doi.org/10.1016/j.tecto.2009.02.026

Tosi L, Da Lio C, Strozzi T, Teatini P (2016) Combining L- and X-band SAR interferometry to assess ground displacements in heterogeneous coastal environments: the Po River Delta and Venice Lagoon, Italy. Remote Sens 8:308. https://doi.org/10.3390/rs8040308

Tozer B, Sandwell DT, Smith WHF, Olson C, Beale JR, Wessel P (2019) Global bathymetry and topography at 15 arc sec: SRTM15+. Earth Space Sci. https://doi.org/10.1029/2019EA000658

Turner W, Rondinini C, Pettorelli N, Mora B, Leidner AK, Szantoi Z, Buchanan G, Dech S, Dwyer J, Herold M, Koh LP, Leimgruber P, Taubenboeck H, Wegmann M, Wikelski M, Woodcock C (2015) Free and open-access satellite data are key to biodiversity conservation. Biol Conserv 182:173-176. https ://doi.org/10.1016/j.biocon.2014.11.048

Twele A, Cao W, Plank S, Martinis S (2016) Sentinel-1-based flood mapping: a fully automated processing chain. Int J Remote Sens 37(13):2990-3004. https://doi.org/10.1080/01431161.2016.1192304

Ullman DS, O’Donnell J, Kohut J, Fake T, Arthur Allen A (2006) Trajectory prediction using HF radar surface currents: Monte Carlo simulations of prediction uncertainties. J Geophys Res 111:C12005. https ://doi.org/10.1029/2006JC003715

UNCTAD (2017) Review of maritime transport 2017. United Nations conference on trade and development. United Nations, Geneva, Switzerland. http://unctad.org/en/PublicationsLibrary/rmt2017_en.pdf

United Nations (UN) (2015) Transforming our world: the 2030 agenda for sustainable development; Resolution adopted by the General Assembly. UN, Rome, Italy

United Nations (UN) (2018) Nineteenth meeting of the united nations open-ended informal consultative process on oceans and the law of the sea: anthropogenic underwater noise. 18-22 June 2018, New York

USACE (1996) Risk-based analysis for flood damage reduction studies, Report EM1110-2-1619. United States Army Corps of Engineers, Washington

Vafeidis AT, Schuerch M, Wolff C, Spencer T, Merkens JL, Hinkel J, Lincke D, Brown S, Nicholls RJ (2019) Water-level attenuation in global-scale assessments of exposure to coastal flooding: a sensitivity analysis. Nat Hazards Earth Syst Sci 19:973-984. https://doi.org/10.5194/nhess-19-973-2019

van der Horst T, Rutten MM, van de Giesen NC, Hanssen RF (2018) Monitoring land subsidence in Yangon, Myanmar using Sentinel-1 persistent scatterer interferometry and assessment of driving mechanisms. Remote Sens Environ 217:101-110. https://doi.org/10.1016/j.rse.2018.08.004

van Sebille E, Griffies SM, Abernathey R, Adams TP, Berloff P, Biastoch A et al (2017) Lagrangian ocean analysis: fundamentals and practices. Ocean Model 121:49-75. https://doi.org/10.1016/j.ocemo d.2017.11.008

van Sebille E et al (2020) The physical oceanography of the transport of floating marine debris. Environ Res Lett 15:023003 
Vanhellemont Q, Ruddick K (2014) Turbid wakes associated with offshore wind turbines observed with Landsat 8. Remote Sens Environ 145:105-115. https://doi.org/10.1016/j.rse.2014.01.009

Vanhellemont Q, Ruddick K (2015) Advantages of high quality SWIR bands for ocean colour processing: EXAMPLES from Landsat-8. Remote Sens Environ 161:89-106. https://doi.org/10.1016/j. rse.2015.02.007

Vanhellemont Q, Ruddick K (2018) Atmospheric correction of metre-scale optical satellite data for inland and coastal water applications. Remote Sens Environ 216:586-597. https://doi.org/10.1016/j. rse.2018.07.015

Vanhellemont Q, Neukermans G, Ruddick K (2014) Synergy between polar-orbiting and geostationary sensors: remote sensing of the ocean at high spatial and high temporal resolution. Remote Sens Environ 146:49-62. https://doi.org/10.1016/j.rse.2013.03.035

Velotto D, Soccorsi M, Lehner S (2014) Azimuth ambiguities removal for ship detection using full polarimetric X-band SAR data. IEEE Trans Geosci Remote Sens 52(1):76-88

Viatte C, Clerbaux C, Maes C, Daniel P, Garello R, Safieddine S, Ardhuin F (2020) Air and sea pollution seen from space. Surv Geophys. https://doi.org/10.1007/s10712-020-09599-0

Villas Bôas AB, Ardhuin F, Ayet A, Bourassa MA, Brandt P, Chapron B, Cornuelle BD, Farrar JT, Fewings MR, Fox-Kemper B, Gille ST, Gommenginger C, Heimbach P, Hell MC, Li Q, Mazloff MR, Merrifield ST, Mouche A, Rio MH, Rodriguez E, Shutler JD, Subramanian AC, Terrill EJ, Tsamados M, Ubelmann C, van Sebille E (2019) Integrated observations of global surface winds, currents, and waves: requirements and challenges for the next decade. Front Mar Sci 6:425. https:// doi.org/10.3389/fmars.2019.00425

Vinogradov SV, Ponte RM (2011) Low-frequency variability in coastal sea level from tide gauges and altimetry. J Geophys Res 116:C07006. https://doi.org/10.1029/2011JC007034

Vousdoukas MI, Mentaschi L, Voukouvalas E, Verlaan M, Jevrejeva S, Jackson LP, Feyen L (2018) Global probabilistic projections of extreme sea levels show intensification of coastal flood hazard. Nat Commun 9:2360. https://doi.org/10.1038/s41467-018-04692-w

Warren MA, Simis SGH, Martinez-Vicente V, Poser K, Bresciani M, Alikas K, Spyrakos E, Giardino C, Ansper A (2019) Assessment of atmospheric correction algorithms for the Sentinel-2A MultiSpectral Imager over coastal and inland waters. Remote Sens Environ 225:267-289. https://doi. org/10.1016/j.rse.2019.03.018

WCRP Global Sea Level Budget Group (2018) Global sea-level budget 1993-present. Earth Syst Sci Data 10:1551-1590

Wegmüller U, Werner C, Strozzi T, Wiesmann A (2004) Multi-temporal interferometric point target analysis. Ser Remote Sens Anal Multi-Tempor Remote Sens Images. https://doi.org/10.1142/97898 12702630_0015

Wegmüller U, Santoro M, Werner C, Strozzi T, Wiesmann A, Lengert W (2009) DEM generation using ERS-ENVISAT interferometry. J Appl Geophys 69:51-58. https://doi.org/10.1016/j.jappg eo.2009.04.002

Weijerman M, Lindeboom H, Zuur AF (2005) Regime shifts in marine ecosystems of the North Sea and Wadden Sea. Mar Ecol Prog Ser 298:21-39. https://doi.org/10.3354/meps298021

Wells S, Ravilious C, Corcoran E (2006) In the front line: shoreline protection and other ecosystem services from Mangroves and Coral Reefs. vol 36. UNEP-WCMC

Werdell PJ, McKinna LI, Boss E, Ackleson SG, Craig SE, Gregg WW, Stramski D et al (2018) An overview of approaches and challenges for retrieving marine inherent optical properties from ocean color remote sensing. Prog Oceanogr 160:186-212

Wiehle S, Pleskachevsky A (2018) Bathymetry derived from Sentinel-1 Synthetic Aperture Radar. EUSAR 2018, https://elib.dlr.de/118174/. Accessed Sept 2019

Wilandsky MJ, Marra JJ, Chowdhury MR, Stephens SA, Miles ER, Fauchereau N, Spillman CM, Smith G, Beard G, Wells J (2017) Multimodel ensemble sea level forecasts for tropical pacific islands. J Appl Meteorol Climatol 56:849-862

Wölfl AC, Snaith H, Amirebrahimi S, Devey CW, Dorschel B, Ferrini V, Huvenne VAI, Jakobsson M, Jencks J, Johnston G, Lamarche G, Mayer L, Millar D, Pedersen TH, Picard K, Reitz A, Schmitt T, Visbeck M, Weatherall P, Wigley R (2019) Seafloor mapping-the challenge of a truly global ocean bathymetry. Front Mar Sci 6:283. https://doi.org/10.3389/fmars.2019.00283

Wong PP, Losada IJ, Gattuso J-P, Hinkel J, Khattabi A, McInnes KL, Saito Y, Sallenger A (2014) Coastal systems and low-lying areas. In: Field CB, Barros VR, Dokken DJ, Mach KJ, Mastrandrea MD, Bilir TE, Chatterjee M, Ebi KL, Estrada YO, Genova RC, Girma B, Kissel ES, Levy AN, MacCracken S, Mastrandrea PR, White LL (ed) Climate change 2014: impacts, adaptation, and vulnerability. Part A: global and sectoral aspects. Contribution of Working Group II to the Fifth 
Assessment Report of the Intergovernmental Panel on Climate Change. Cambridge University

Press, Cambridge, pp 361-409

Woodworth P, Hunter JR, Marcos M, Caldwell P, Menéndez M, Haigh I (2017) Towards a global higherfrequency sea level dataset. Geosci Data J 3:50-59

Woodworth P, Melet A, Marcos M, Ray RD, Wöppelmann G, Sasaki YN, Cirano M, Hibbert A, Huthnance JM, Montserrat S, Merrifield MA (2019) Forcing factors affecting sea level changes at the coast. Surv Geophys 40(6):351-1397. https://doi.org/10.1007/s10712-019-09531-1

Wöppelmann G, Le Cozannet G, De Michele M, Raucoules D, Cazenave A, Garcin M, Hanson S, Marcos M, Santamaría-Gómez A (2013) Is land subsidence increasing the exposure to sea level rise in Alexandria, Egypt? Geophys Res Lett 40(12):2953-2957. https://doi.org/10.1002/grl.50568

Yang Y, Pepe A, Manzo M, Bonano M, Liang DN, Lanari R (2013) A simple solution to mitigate noise effects in time-redundant sequences of small baseline multi-look DInSAR interferograms. Remote Sens Lett 4(6):609-618

Ye S, Luo Y, Wu J, Yan X, Wang H, Jiao X, Teatini P (2016) Three-dimensional modeling of land subsidence in Shanghai, China. Hydrogeol J 24(3):695-709. https://doi.org/10.1007/s1004 0-016-1382-2

Zanello F, Teatini P, Putti M, Gambolati G (2011) Long term peatland subsidence: experimental study and modeling scenarios in the Venice coastland. J Geophys Res Earth Surface 116:F04002. https://doi. org/10.1029/2011JF002010

Zechetto S, De Biasio F, Della Valle A, Cucco A, Quattrocchi G, Cadau E (2016) Wind fields from COSMOSKYMED and Radarsat-2 SAR in coastal areas. In: IEEE international geoscience and remote sensing symposium (IGARSS), IEEE, pp 1535-1538. https://doi.org/10.1109/IGARSS.2015.7326073

Zhang Y, Wang C, Wu J, Qi J, Salas WA (2009) Mapping paddy rice with multitemporal ALOS/PALSAR imagery in southeast China. Int J Remote Sens 30(23):6301-6315. https://doi.org/10.1080/01431 160902842391

Zhang Y, Wu H, Kang Y, Zhu C (2016) Ground subsidence in the Beijing-Tianjin-Hebei region from 1992 to 2014 revealed by multiple SAR stacks. Remote Sens 8(8):675. https://doi.org/10.3390/rs8080675

Zoccarato C, Minderhoud PSJ, Teatini P (2018) The role of sedimentation and natural compaction in a prograding delta: insights from the mega Mekong delta, Vietnam. Sci Rep 8:11437. https://doi. org/10.1038/s41598-018-29734-7

Publisher's Note Springer Nature remains neutral with regard to jurisdictional claims in published maps and institutional affiliations.

\section{Affiliations}

\section{A. Melet ${ }^{1}$ (D) P. Teatini ${ }^{2} \cdot$ G. Le Cozannet ${ }^{3} \cdot$ C. Jamet $^{4} \cdot$ A. Conversi ${ }^{5} \cdot$ J. Benveniste $^{6}$. R. Almar ${ }^{7}$}

1 Mercator Ocean International, 8 rue Hermès, 31520 Ramonville-Saint-Agne, France

2 Department of Civil, Environmental and Architectural Engineering, University of Padova, Via Marzolo 9, 3531 Padua, Italy

3 BRGM, 45000 Orléans, France

4 Univ. Littoral Cote d'Opale, Univ. Lille, CNRS, UMR 8187, LOG, Laboratoire d'Océanologie et de Géosciences, 62930 Wimereux, France

5 National Research Council of Italy, CNR-ISMAR-Lerici, Forte Santa Teresa, Loc. Pozzuolo, 19032 Lerici, SP, Italy

6 European Space Agency (ESA-ESRIN), Largo Galileo Galilei, 1, 00044 Frascati, Italy

7 LEGOS, Université de Toulouse, CNES, CNRS, IRD, UPS, 31400 Toulouse, France 